\title{
Laccase immobilization via cross-linked aggregate preparation: Characterization, thermodynamic/kinetic properties and application in removal of bisphenol $\mathrm{A}$ from solutions
}

Adedeji Ademakinwa ( $\sim$ adedeji.ademakinwa@elizadeuniversity.edu.ng )

EU: Elizade University https://orcid.org/0000-0001-7736-0459

Research Article

Keywords: CLEA, laccase, RSM, biodegradation, Bisphenol A

Posted Date: March 5th, 2021

DOl: https://doi.org/10.21203/rs.3.rs-267600/v1

License: (c) (i) This work is licensed under a Creative Commons Attribution 4.0 International License.

Read Full License 
1 Laccase immobilization via cross-linked aggregate preparation: Characterization, 2 thermodynamic/kinetic properties and application in removal of bisphenol A from solutions

5 Department of Physical and Chemical Sciences, Elizade University, Ilara-Mokin, Ondo-State. 
24 Abstract

25 Fungal laccase from Aureobasidium pullulans was immobilized via cross-linked enzyme 26 aggregate (CLEA) preparation under statistically optimized conditions. The stability of the 27 CLEA to heat inactivation was studied via investigation of its thermodynamic and kinetic 28 parameters. The immobilized enzyme was then deployed in the biodegradation of a bisphenol-A 29 (BPA). The optimum conditions for CLEA preparation resulting in the highest immobilization 30 yield were ammonium sulphate $(60 \% \mathrm{v} / \mathrm{v})$, glutaraldehyde $(30 \mathrm{mM}), \mathrm{pH}(4.5)$, time $(6 \mathrm{~h})$ and 31 temperature $\left(55^{\circ} \mathrm{C}\right)$. The CLEA retained about $51 \%$ of its activity after eight catalytic cycles. The 32 optimum $\mathrm{pH}$ and temperature of the laccase CLEA were 5.5 and $60^{\circ} \mathrm{C}$ respectively. The SEM 33 indicated that the laccase CLEA was type II (unstructured). The data obtained from the heat 34 inactivation kinetics and thermodynamic characterization indicated that the CLEA was stable 35 to heat denaturation than the free enzyme. The kinetic parameters obtained for the CLEA with 36 ABTS as substrate were $101.3 \mu \mathrm{M}, 2.94 \mu \mathrm{mols}-1 \mathrm{mg}-1$ and $0.03 \mathrm{dm} 3 \mathrm{~s}-1 \mathrm{mg}-1$ for the $\mathrm{Km}$, Kcat 37 and $K c a t / K m$ respectively. The optimum conditions for BPA biodegradation using the CLEA 38 were temperature $\left(55^{\circ} \mathrm{C}\right)$, time $(2 \mathrm{~h})$, CLEA $(1.0 \mathrm{mg})$ and BPA concentration $(40 \mathrm{mg} / \mathrm{L})$. After the 39 7th cycle, laccase CLEA retained about $63 \pm 2.3 \%$ biodegradation efficiency. A heat-resistant 40 laccase CLEA was able to remove BPA from solutions under statistically optimized conditions. 41 The laccase CLEA has properties for other futuristic applications.

42 Keywords: CLEA, laccase, RSM, biodegradation, Bisphenol A 


\section{Introduction}

48 Laccases (multicopper oxidases) are useful enzymes mostly in the industry as they play roles 49 such as in xenobiotic biodegradation, pulp and paper bleaching etc. They can perform these 50 functions due to their low substrate specificity and potentials in the oxidation of a large number 51 of substrates [1]. Substrate oxidation is often accompanied by the release of oxygen to water. 52 Moreso, laccases are often regarded as being environmentally friendly, hence, its application in 53 numerous field is quite understandable [2]. Laccases have been reported to be involved in the 54 removal of pollutants such as endocrine-disrupting chemicals and dyestuff (EDC) [3, 4]. These 55 EDC's are present in wastewater bodies and are known to cause deleterious effects on human 56 and animal health [5]

57 Major hindrances to the application of laccases (in an aqueous form) industrially especially in 58 xenobiotics biodegradation is the low yields and very high costs, loss of enzyme activity and poor 59 reusability [6]. These problems are often solved via immobilizing the enzymes because the use 60 of immobilized enzymes provides options for cost reduction, enzyme stability and enhanced 61 reusability [7]. Several techniques of laccase immobilization for BPA biodegradation exists with

62 the most prominent one being immobilization on a solid support [6]. This technique comes with 63 usual problems such as low enzyme: solid support. This brings about the technique of deploying 64 cross-linked enzyme aggregates (CLEA) [8, 9]. This technique is devoid of solid support as it 65 involves precipitating the enzyme and then cross-linking it with a cross-linker such as 66 glutaraldehyde. The production of laccase CLEA's has been reported in the literature. Laccase 67 CLEA's are known to be thermostable and resistant to denaturants.

68 The preparation of laccase CLEA from the fungus, Aureobasidium pullulans with a focus on its 69 application in the biodegradation of endocrine-disrupting compounds was the main objective of 
70 this study. There are reports of production of extracellular laccase by this fungus $[10,11]$. The 71 utilization of laccase and mycelia from this fungus in the biodegradation of textile dyes has been 72 reported [12]. This study is the first-ever for the immobilization of laccase via CLEA from this 73 fungus. Despite the numerous advantages posed by using CLEA, very few reports exist in 74 literature where laccase CLEA was produced for applications in BPA biodegradation. Only the 75 report of Cabana et al. [3] established the application of CLEA in the removal of BPA using a 76 fluidized bed reactor. Most recent studies on CLEA and its application focused on dye 77 biodegradation [13]. Hence, this study provides needed information on the application of laccase 78 CLEA in the removal of EDC's.

79 In this study, the use of response surface methodology via central composite rotatable design 80 (CCRD) was utilized in both the preparation of the CLEA and its application in the 81 biodegradation of BPA. During optimization of most bioprocesses, CCRD provides unique 82 advantages such as easy monitoring of the several interactive variable effects [14].

\section{Methods}

\section{$84 \quad$ Fungal growth and enzyme isolation}

85 Aureobasidium pullulans was maintained on malt extract agar and sub-cultured every 4 days 86 at $23 \pm 1^{\circ} \mathrm{C}$. The fungus was inoculated into a laccase-producing medium containing (in $\mathrm{g} / \mathrm{L}$ ):

87 CuSO4. 5H2O (4) Tyrosine (3.0), glucose (10), ZnSO4 (0.1), FeSO4 (0.05), MnSO4 (0.5), MgSO4 88 (0.5) yeast extract (5). Growth was monitored for 5 days and the mycelia was harvested after 89 centrifugation at $6000 \mathrm{x}$ g for $10 \mathrm{~min}$. The mycelia (10 g) was homogenized using acid-washed 90 sand (in a sterile and pre-chilled mortar/pestle) in 1:1 ratio [15] Thereafter, three-time volume 91 of $10 \mathrm{mM}$ citrate buffer $\mathrm{pH} 4.0$ buffer (chilled at $4^{\circ} \mathrm{C}$ ) was added to the homogenized mycelia and 
92 it was stirred. All operations were carried out on ice at $4^{\circ} \mathrm{C}$. The homogenate was centrifuged at

$936000 \mathrm{xg}$ for $30 \mathrm{~min}$ at $4^{\circ} \mathrm{C}$ and the resulting supernatant served as the source of enzyme.

\section{$94 \quad$ Laccase assay and protein concentration determination}

95 Laccases was assayed using $13 \mathrm{mM}$ ABTS as substrate [10]. ABTS oxidation was monitored at $96460 \mathrm{~nm}$. One unit of laccase activity was defined as the amount of enzyme that oxidizes one 97 micromole of substrate to form the product ABTS+ in one min. Protein concentration was 98 determined using bovine serum albumin as standard via methods described by Bradford [16].

99 Preparation of CLEA

\section{Selection of precipitant}

101 The choice of precipitant was determined over a concentration range of $0-70 \% \mathrm{v} / \mathrm{v}$ of each chilled 102 precipitant (acetone, ethanol, ammonium sulphate, PEG-2000, PEG-5000). The precipitants 103 were added to the enzyme solution in a $10 \mathrm{ml}$ centrifuge tube and incubated for $8 \mathrm{~h}$ at $4^{\circ} \mathrm{C}$. The 104 enzymatic activity of the aggregates were determined with ABTS as substrate.

105 CLEA synthesis via optimization

106 In preliminary studies, the CLEA was synthesized by using the methods described by Cabana 107 et al.3 and Ademakinwa et al.[17]. Briefly, $2 \mathrm{ml}$ of $800 \mathrm{mU} / \mathrm{mL}$ of laccase was added to $4 \mathrm{ml}$ of 108 ammonium sulphate $(50 \% \mathrm{v} / \mathrm{v})$. After a $16 \mathrm{~h}$ incubation, the reaction mixture was centrifuged at $3500 \mathrm{x}$ g for $10 \mathrm{~min}$ at $4^{\circ} \mathrm{C}$. The pellet was collected and re-dissolved in minute amount of buffer (10 mM citrate-phosphate $\mathrm{pH} 4.0)$. Thereafter, $2 \mathrm{ml}$ of glutaraldehyde ( $25 \mathrm{mM})$ was added to the re-dissolved pellet and it was allowed to cross-link for $2 \mathrm{~h}$ at $4^{\circ} \mathrm{C}$. The resulting pellet was collected by centrifugation at $3500 \mathrm{xg}$ for $10 \mathrm{~min}$ at $4^{\circ} \mathrm{C}$. The pellet was washed in $10 \mathrm{mM}$ citrate-phosphate buffer, $\mathrm{pH} 4.0$ and stored at $4 \mathrm{C}$. The immobilization yield was determined using the equation below 
115 Immobilization yield $(\%)=\frac{\text { Specific activity of immobilized enzyme }}{\text { Specific activity of free enzyme }}$

116 To optimize CLEA preparation, response surface methodology via central composite design was 117 adopted. Five independent variables (at five unique levels) were considered such as precipitant 118 concentration, precipitation time, glutaraldehyde concentration, cross-linking time and 119 temperature. The experimental design was generated using Design-Expert version 6.0.

120 The high and low levels of the process variables adopted for the RSM optimization were 121 determined from results of preliminary experiments (not shown). The precipitation 122 concentration 10 and $50 \%(\mathrm{v} / \mathrm{v})$, precipitation time 4 and $16 \mathrm{~h}$, glutaraldehyde concentration 2 123 and $30 \% \mathrm{v} / \mathrm{v}$; cross-linking time 3 and $12 \mathrm{~h}$ and temperature 30 and $70^{\circ} \mathrm{C}$. The CCRD is shown 124 in Supplementary S1 and it illustrates the five variables studied at the five different levels, the 125 observed and residual activity of the CLEA. The five different levels for the individual 126 experiment were coded thus: $-\alpha,-1,0,1,+\alpha$.

$127 \quad \alpha=2^{N / 4}$ where $N$ is the number of variable

\section{Data analysis}

129 Equation 1 illustrates the analysis of the experimental data for each independent variable by 130 fitting of the second-order polynomial equation to the experimental data of each dependent 131 variable.

$X_{i}=\mu_{0}+\sum_{i=1}^{n} \mu_{i} x_{i}+\sum_{i=1}^{n-1} \sum_{j=i+1}^{n} \mu_{i j} x_{j}+\sum_{i=1}^{n} \mu_{i i} x_{i}^{2}$

$133 X_{i}$ is the response (\%Immobilization yield); $x_{i}$ represents the independent variables considered 134 in this study, i.e. $\mathrm{x} 1$ : precipitant concentration $[\% \mathrm{v} / \mathrm{v}], \mathrm{x} 2$ : precipitation time $[\mathrm{h}], \mathrm{x} 3$ : 135 glutaraldehyde concentration [\% v/v]; $\mathrm{x} 4$ : cross-linking time $[\mathrm{h}]$ and $\mathrm{x} 5$ : temperature [C]. $136 \mu_{0}$ represent the value of the fitted response at the central points. The liner, interactive and 137 quadratic terms are designated by $\mu_{i}, \mu_{i j}$ and $\mu_{i i}$ respectively. 


\section{CLEA characterization}

Effect of $\mathrm{pH}$ and temperature

140 The effect of $\mathrm{pH}$ on the free enzyme and CLEA was determined using several buffers: $10 \mathrm{mM}$ 141 citrate-phosphate buffer $\mathrm{pH}$ 3.0-5.0, phosphate buffer 6.0-8.0, Tris-HCl buffer 9.0-11.0. The 142 effect of temperature on CLEA was determined at temperatures ranging from 20 to $90^{\circ} \mathrm{C}$ with 143 ABTS as substrate.

\section{$144 \quad$ pH and heat stability studies}

145 CLEA was incubated at optimum $\mathrm{pH}$ for $8 \mathrm{~h}$ and the residual activity determined every $1 \mathrm{~h}$ with 146 ABTS as the substrate. For the heat stability studies, the CLEA was incubated at 40 to $80^{\circ} \mathrm{C}$ for $1476 \mathrm{~h}$ and the residual activity was estimated.

\section{Heat inactivation kinetics of the free enzyme and CLEA}

149 The irreversible heat inactivation process is often kinetically described by a first-order reaction, 150 see equation (4)

$151 v=k_{d} E[2]$

152 where $v$ is defined as the rate of inactivation of the enzyme and $E$ is the concentration of the 153 active form of the enzyme. The $k_{d}$ is obtained from the slopes of the plot of the activity coefficient, $154 \rho$, against time at different temperature range $\left(40-80^{\circ} \mathrm{C}\right)$ i.e. In $\rho$ vs $t$. From the Arrhenius plot, 155 In $k_{d} v s 1 / T$, the energy of thermal denaturation, $E_{d}$, was estimated from the slopes of the 156 straight lines. Other thermodynamic parameters were estimated from the equations stated 157 below as described by Melikoglu et al. [18].

$158 \Delta H_{d}^{*}=E_{d}-R T$

$159 \Delta G_{d}^{*}=-R \operatorname{TIn}\left(\frac{k_{d} h}{k_{b} T}\right)$

$160 \Delta S_{d}^{*}=\frac{\Delta H^{*}-\Delta G^{*}}{T}$ 
$\Delta H_{d}{ }^{*}$ : Change in enthalpy

$162 \Delta G_{d}{ }^{*}:$ Gibb's free energy

$163 \Delta S_{d}{ }^{*}$ : Change in entropy

164 R: universal gas constant $(=8.314 \mathrm{~J} / \mathrm{mol} / \mathrm{K})$

165 h: Planck's constant $(=6.63 \times 10-34)$

$166 \quad k_{b}$ : Boltzmann constant $(=1.38 \times 10-23)$

167 The half-life of the enzyme, $t_{1 / 2}$, was determined according to the equation described below.

$168 t_{1 / 2}=0.693 / k_{d}$

169 Determination of kinetic parameters

170 The kinetic parameters for the immobilized laccase were determined using ABTS (25-1500 $\mu \mathrm{M})$

171 as substrate. The kinetic parameters (Km, Kcat and Vmax) were determined from the Michealis-

172 Menten plot (v against S) using the GraphPad Prism software version 7.0.

\section{SEM and FTIR studies}

174 The surface structure of the CLEA was determined by FTIR spectroscopy in a transmittance 175 mode while the structural features of the CLEA was investigated using SEM. For the SEM 176 studies, the dried CLEA was coated with gold, viewed under $2500 \mathrm{X}$ magnification under $10 \mathrm{kV}$ 177 using scanning electron microscope model TESCAN. For the FTIR studies, the dried CLEA was 178 ground in a mortar containing $\mathrm{KBr}$ (in 1:1) and screwed to pellets [17]. Scans were recorded 179 from 4000-400 cm in transmittance mode using a Shimadzu FTIR-8400S spectrophotometer.

\section{Biodegradation efficiency of BPA by CLEA}

181 The potential of the CLEA to biodegrade BPA was investigated under response surface 182 methodology via CCRD (described earlier) only that in this case, the response is \% 183 biodegradation efficiency and the independent variables are concentration of the BPA $(\mathrm{mg} / \mathrm{L})$, 
184 time of incubation (h), temperature (C) and CLEA amount (mg). Supplementary S2 provides the information on the CCRD experimental design and it illustrates the four variables studied at 186 five different levels. As seen in equation 3,

$187 X_{i}$ is the response (\% Biodegradation efficiency); $x_{i}$ represents the independent variables considered in this study, i.e. $\mathrm{x} 1$ : BPA concentration, $[\mathrm{mg} / \mathrm{L}], \mathrm{x} 2$ : time of incubation $[\mathrm{h}], \mathrm{x} 3$ : CLEA amount

[mg]; $\mathrm{x} 4$ : temperature $[\mathrm{C}]$. $\mu_{0}$ represent the value of the fitted response at the central points. The liner, interactive and quadratic terms are designated by $\mu_{i}, \mu_{i j}$ and $\mu_{i i}$ respectively.

$192 \%$ Biodegradation Efficiency $=\left(1-\frac{[B P A]_{t}}{[B P A]_{0}}\right) x 100$

193 Where $[B P A]_{t}$ and $[B P A]_{o}$ represent the BPA concentration at a specified time after treatment 194 with CLEA and the initial BPA concentration respectively.

\subsubsection{Model validation}

196 To validate the model, the optimum conditions obtained in the experimental runs were repeated 197 at least three times and the biodegradation efficiency determined.

\subsubsection{Reusability of CLEA in BPA biodegradation}

199 The CLEA was used in the biodegradation of BPA at the optimum conditions for several catalytic 200 cycles. The experiment was repeated thrice and the biodegradation efficiency determined.

\section{Result and discussion}

\section{Selection of best precipitating agent for laccase prior to cross-linking}

It was observed that acetone had the least recovery at all concentrations studied $(0-75 \% \mathrm{v} / \mathrm{v})$.

The reduced recovery might be due to the acetone inducing certain changes in structural properties of the laccase, which resulted in a loss of enzymatic activity. Ammonium sulphate had the highest recovery of about $80 \%$ at $65 \%(\mathrm{v} / \mathrm{v})$. The choice of precipitant for laccase is 
necessary because of the recovery obtained after precipitation and the change in structural conformation/enzymatic features afterwards [8]. The conclusion that ammonium sulphate was the best precipitating agent prior to crosslinking was also reported by Yang et al. [19].

\section{Statistical optimization of the preparation of laccase CLEA}

From Supplementary S1, it was observed that the optimum conditions resulting in the highest yield (73\%) for the laccase CLEA were ammonium sulphate $(60 \% \mathrm{v} / \mathrm{v})$, glutaraldehyde $(30 \mathrm{mM})$, $\mathrm{pH}(4.5)$, time $(6 \mathrm{~h})$ and temperature $\left(55^{\circ} \mathrm{C}\right)$. The second order RSM obtained via ANOVA of the immobilization yield is provided in Table 1. The model $\mathrm{F}$ value of 36.31 indicated that the model was significant which implied that there was a $0.01 \%$ chance that this model could occur due to noise. The standard deviation, coefficient of variation, adequate precision and coefficient of determination values were $1.27,1.92,23.80$ and 0.96 respectively. The p-value obtained was less than 0.0001and it indicated that the model was significant. Other significant parameters included from the viewpoint of the p-value were $X_{1}, X_{2}, X_{3}, X_{4}, X_{5}$, $X_{1} X_{2}, X_{1} X_{3}, X_{1} X_{4}, X_{1} X_{5}, X_{2} X_{3}, X_{2} X_{5}$ and $X_{4} X_{5}$. The implications of the significance of these variables is that they provide information that these variables affect the immobilization yield. Other parameters were not significant $(\mathrm{p}>0.05)$ indicating that those variables had no profound effect on the immobilization yield of the laccase CLEA.

A second-order polynomial equation was obtained that described the link between the variables studied and the response (immobilization yield). The equation is described as:

Immobilization Yield $(\%)=70.91-3.96 X_{1}+0.57 X_{2}+1.29 X_{3}-0.83 X_{4}+0.46 X_{5}-1.57 X_{1}^{2}-$ $0.37 X_{2}^{2}-1.57 X_{3}^{2}-1.39 X_{4}^{2}-0.69 X_{5}^{2}+0.46 X_{1} X_{2}-0.27 X_{1} X_{3}-0.85 X_{1} X_{4}+0.38 X_{1} X_{5}+0.26 X_{2} X_{3}-$ $0.52 X_{2} X_{4}-0.060 X_{2} X_{5}-0.31 X_{3} X_{4}+0.39 X_{3} X_{5}+0.24 X_{4} X_{5}$

The variables were coded such that, $\mathrm{x} 1$ : precipitant concentration $[\% \mathrm{v} / \mathrm{v}], \mathrm{x} 2$ : precipitation time [h], x3: glutaraldehyde concentration $[\% \mathrm{v} / \mathrm{v}] ; \mathrm{x} 4$ : cross-linking time $[\mathrm{h}]$ and $\mathrm{x} 5$ : temperature $\left[{ }^{\circ} \mathrm{C}\right]$. To critically understand the interactions between the variables considered in this study and how it influences the response (immobilization yield), response surface plots (Supplementary S3) 
233 were obtained for two variables while the others are kept at a constant (central levels). For 234 example, the effects of $\mathrm{pH}$ and time (while precipitant and glutaraldehyde concentration and 235 temperature were kept constant at their central levels) on the CLEA immobilization yield is 236 provided in Fig. 1. It was observed that the immobilization yield gradually increased as both the 237 time and $\mathrm{pH}$ values were increased until the optimum was reached. Further increased above 238 the optimum values led to decreases in the response.

\section{Model Validation}

240 The immobilization yield obtained after repeating the experiments under the optimum 241 conditions predicted by the model was $75.3 \pm 2.8 \%$ which was very close to that predicted by the 242 model. The immobilization yield obtained for laccase CLEA was higher than the values obtained 243 for laccase CLEA from Cerrena sp. [19] and Coriolopsis polyzona [3] which had values of $68.1 \%$ 244 and $60.2 \%$ respectively.

\section{Reusability of CLEA}

246 Supplementary $\mathrm{S} 4$ shows the potential of the laccase CLEA to catalyze ABTS oxidation over 247 several cycles of catalysis. After eight reaction cycles, the resulting immobilization yield was $24851 \%$. A gradual decrease in the rate of catalysis was observed after the fifth cycle and this might 249 be due to substrate mass-transfer limitations that result in a decreased rate of ABTS oxidation 250 by the CLEA.

\section{Laccase CLEA characterization}

\section{Effect of $\mathbf{p H}$ and temperature}

253 The optimum pH obtained for the free laccase and CLEA were 4.5 and 5.5 respectively (Fig.2). 254 The optimum $\mathrm{pH}$ of most fungal laccases falls within the acidic region [20]. The $\mathrm{pH}$ of the CLEA 255 increased by a unit when compared with the free enzyme. This increase could be due to the 
256 changes in the microenvironment of the immobilized enzyme. This observation was in 257 agreement with the reports of several authors [21,22]. The optimum temperature for the free 258 laccase and CLEA were 40 and $60^{\circ} \mathrm{C}$ respectively (Fig. 3). Most immobilized laccases have an 259 optimum temperature that falls within 40 and $60^{\circ} \mathrm{C}[20]$.

\section{pH and temperature stability}

261 The $\mathrm{pH}$ stability is shown in Supplementary S5. It was noted that after $4 \mathrm{~h}$ incubation the free 262 laccase retained about $100 \%$ of its initial activity at $\mathrm{pH} 4.5$. This decreased after $5 \mathrm{~h}$ incubation 263 with a loss of about $5 \%$. Upon the increase of the incubation time to $8 \mathrm{~h}$, the free laccase retained 264 about $85 \%$ of its residual activity. The results obtained in this study was in agreement with what Lassaoune et al. [21] obtained for free laccase where the enzyme retained about $85.2 \%$ 266 after incubation. Meanwhile, the CLEA retained more than $95 \%$ of its initial enzymatic activity 267 after $8 \mathrm{~h}$ incubation at $\mathrm{pH} 5.5$

268 The thermostability of the free laccase is shown in Supplementary S6. It was observed that after $2698 \mathrm{~h}$ incubation at $40^{\circ} \mathrm{C}$, the free laccase retained about $80 \%$ of its initial activity. It was observed 270 that at very high temperatures $\left(60-80^{\circ} \mathrm{C}\right)$ more than $80 \%$ of the initial activity was lost. 271 Supplementary S8 illustrates the thermostability of the laccase CLEA. It was noted that after $2728 \mathrm{~h}$ incubation, at $40-50^{\circ} \mathrm{C}$, the laccase CLEA retained more than $90 \%$ of its initial activity. 273 Increase of the temperature from $50-60^{\circ} \mathrm{C}$ still showed that the immobilized enzyme retained 274 more than $75 \%$ of its initial activity after $8 \mathrm{~h}$ incubation. A drastic drop to about $55 \%$ of its initial 275 activity was observed after the incubating temperature was increased to $80^{\circ} \mathrm{C}$ after $8 \mathrm{~h}$ 276 incubation. It was concluded that the laccase CLEA was more thermostable than the free 277 enzyme. The thermostability of CLEA or other immobilized enzymes over their free enzyme has 278 been reported in recent literature [17, 21, 23-25] 


\section{Heat inactivation studies}

280 Table 2 shows the summary of the kinetic and thermodynamic parameters for both the free and

281 immobilized laccase. Both enzyme form's enzymatic activity decayed in a typical first-order heat 282 inactivation pattern. This inactivation pattern is similar to other enzymes produced by this 283 fungus [15, 23-25].

284 The values of the first-order thermal denaturation constant, $k_{d}$, for the CLEA (0.0113-0.0791 h285 1) and the free laccase $(0.0317-0.1995 \mathrm{~h}-1)$ is indicated in Table 2 . These $k_{d}$ values were initially 286 obtained from the plot of In $\left(\frac{E}{E o}\right) v s$ time (see supplementary S7 and S9) and they increased as 287 the temperature was gradually raised. At any temperature range considered, the $k_{d}$ values 288 obtained for the CLEA lower than the free enzyme. This also implies that the immobilized 289 enzyme displayed a greater degree of thermostability at each temperature increase than the 290 free enzyme. Several authors have reported that immobilized forms of the enzyme tend to be 291 more thermally stable than the free enzyme [23, 24].

292 From Table 2, the half-life $\left(t_{1 / 2}\right)$ values for both free laccase and laccase CLEA decreased 293 progressively while the heat inactivation constant increased as the temperature was gradually 294 increased from 40 to $80^{\circ} \mathrm{C}$. A higher $t_{1 / 2}$ value is required if the enzyme is to applied industrially 295 [26]. The laccase CLEA prepared in this study had very high $t_{1 / 2}$ even at higher temperatures 296 and hence could be useful in numerous industrial applications.

297 The values energy of thermal inactivation, $E_{d}$, for both enzyme forms were obtained from the 298 plot indicated in Fig. 4. $E_{d}$ values obtained for both free and immobilized laccase were $39.9\left(R^{2}=\right.$ $2990.86)$ and $42.4\left(R^{2}=0.96\right) \mathrm{kJ} / \mathrm{mol} / \mathrm{K}$ for free laccase and CLEA respectively. It was observed that 300 the $E_{d}$ values for the CLEA was higher than the free enzyme. This further attests to the fact 
301 that the free enzyme was relatively less stable to thermal inactivation compared to the laccase 302 CLEA.

303 The $E_{d}$ is directly related to the enthalpy of thermal inactivation, $\Delta H_{d}$. The $\Delta H_{d}$ values provide 304 information on the overall energies necessary to cause heat inactivation of proteins. Therefore, 305 it can be suggested that a high value of $\Delta H_{d}$ and $E_{d}$ indicates increased resistance to heat [27]. 306 The laccase CLEA had higher values of $\Delta H_{d}$ compared to the free enzyme (Table 2).

307 The degree of heat-mediated inactivation of enzymes is quite dependent on the entropy of 308 thermal inactivation, $\Delta S_{d .} \Delta S_{d}$ values indicate the energies required for the transition from a 309 native $(\mathrm{N})$ to a denatured state $(\mathrm{U})(\mathrm{N} \leftrightarrow I \leftrightarrow U)$. Every thermal inactivation process leads to 310 changes in the enzyme conformation leading to increased orderliness and randomness (or 311 positive values for $\Delta S_{d}$ ) [28]. In this study, the negative values obtained for $\Delta S_{d}$ for both free 312 laccase (-162.3 to $-155.0 \mathrm{~J} / \mathrm{mol} / \mathrm{K})$ and CLEA ( -155.6 to $-155.5 \mathrm{~J} / \mathrm{mol} / \mathrm{K})$ is suggestive of even more 313 increased resistance to disorderliness. This means that both enzyme forms were resistant to 314 heat inactivation. A comparative look into the $\Delta S_{d}$ values obtained for both free and laccase 315 CLEA, it can be concluded that the process of CLEA preparation (precipitating with ammonium 316 sulphate and crosslinking with glutaraldehyde) allowed for more orderliness which 317 concomitantly increased its thermal stability. This conclusion was also reached for protease [28], 318 rhodanese [24], cellulase [23].

319 The values for Gibb's free energy $\left(\Delta G_{d}\right)$ obtained for the free laccase $(88.1$ to $91.7 \mathrm{~kJ} / \mathrm{mol})$ and 320 laccase CLEA ( 88.5 to $94.4 \mathrm{~kJ} / \mathrm{mol}$ ) is provided in Table 3 . The $\Delta G_{d}$ values obtained for both the 321 free and laccase CLEA were quite very close. This is indicative of thermostability. 
322 When all thermodynamic and kinetic parameters were taken into consideration, it was 323 confidently asserted that the CLEA was very stable to thermal denaturation even at very high 324 temperatures $\left(50-60^{\circ} \mathrm{C}\right)$ compared to the free laccase.

\section{5}

\subsubsection{Kinetic Parameters for laccase CLEA}

The $K_{M}$ for free laccase $(106.2 \mu \mathrm{M})$ and CLEA $(101.3 \mu \mathrm{M})$ was obtained from the MichaelisMenten plot (vagainst $S$ ) with ABTS as substrate. These values were about the same. This observation was quite similar to the report of Cabana et al. [3] for free laccase and laccase CLEA. The $K_{\text {cat }}$ obtained in this study for the free laccase and the laccase CLEA were 1.94 and 2.94 ( $\mu \mathrm{mol} / \mathrm{s} / \mathrm{mg}$ ) respectively. The rate of catalysis by the CLEA was approximately twice that of the free enzyme as observed from the $K_{c a t}$ values. The values obtained in this study is quite lower than what was obtained for laccase CLEA from C. polyzona [3] (which was six times higher than the free enzyme). Another kinetic parameter of great importance is the catalytic efficiency, $K_{c a t} / K_{M}$. From the $K_{c a t} / K_{M}$ values obtained for the free $\left(0.04 \mathrm{dm}^{3} \mathrm{~s}^{-1} \mathrm{mg}^{-1}\right)$ and immobilized laccase $\left(0.06 \mathrm{dm}^{3} \mathrm{~s}^{-1} \mathrm{mg}^{-1}\right)$, it can be concluded that the catalytic efficiency in the CLEA is approximately twice that of the free enzyme. This suggests the laccase CLEA had a better overall catalytic potential than the free enzyme.

\subsubsection{SEM and FTIR studies on CLEA}

The FTIR spectra of the laccase CLEA is shown in supplementary S10. Several characteristic peaks were noted such as the peaks at $1647 \mathrm{~cm}-1$ which is indicative of the amide I (carbonyl stretching $\mathrm{C}=\mathrm{O}$ ). Another peak that represents the bending and stretching of both $\mathrm{C}-\mathrm{N}$ and $\mathrm{N}$ H [17]. The SEM of the CLEA is indicated in Fig. 5. Typically, CLEA structure from SEM falls into two categories, the ball type (type 1) and unstructured (type 2) [29]. From the SEM, it was evident that the laccase CLEA falls into type 2. 


\subsection{RSM-modelled biodegradation of BPA using laccase CLEA}

The optimum conditions predicted by the mathematical model were BPA (40 mg/L), time (2 h),

temperature $\left(55^{\circ} \mathrm{C}\right)$ and CLEA amount (1.0 $\mathrm{mg}$ ) (Supplementary S2). The optimum conditions

resulted in a biodegradation efficiency of 99.9\%. Asagdol et al. [30] reported the removal of BPA

with an efficiency of $88.3 \%$ by the free laccase which was lower than that obtained for the

350 immobilized enzyme used in this study or reported elsewhere [21]. The results obtained in this

351 study was quite similar to the findings of Lassaoune et al. [21] where it was reported that laccase

352 immobilized by cross-linking prior to entrapment in alginate had a biodegradation efficiency of $35399 \%$.

354 From Table 3, the R2, standard deviation and, CV were 0.97, 5.91 and 11.39 respectively. The 355 model-F value obtained in this study was 34.56 and the model was deemed significant $356(p<0.0001)$. A model-F value that is as large as the one obtained in this study has a $0.01 \%$ chance 357 it occurred due to noise. Significant model terms (based on the values of "Prob>F" less than 0.05) 358 where A, C, D, A2, B2, D2 and AD. The final equation in terms of the coded factor was:

\%Biodegradation Efficiency $=+65.68-21.92 A-1.77 B+8.50 C-5.87 D-3.63 A^{2}-4.01 B^{2}-$ $1.25 C^{2}-8.41 D^{2}-1.31 A B-2.47 A C+3.74 A D+1.48 B C+0.51 B D-1.37 C D$

The response surface plots are shown in supplementary S11. S11 (a) examines the effects of time and temperature on the BE. It was observed that increasing the temperature increased the BE by the CLEA. Meanwhile, when the optimum time was reached for maximum BE by the CLEA, a gradual decrease in the BE was noted. S11 (b) illustrates the effects of time and BPA concentration on the BE of the CLEA. It was noted that a steady decline in the BE was observed 366 as the BPA concentration was increased above the optimum value. It can be deduced that 
367 perhaps, the CLEA enzymatic activity had been inhibited either by the substrate (BPA) or the 368 products formed.

\section{$369 \quad$ 3.5.1 Model validation of BPA biodegradation by laccase CLEA}

370 The optimum conditions predicted by the model were validated under the following 371 experimental conditions: temperature $\left(55^{\circ} \mathrm{C}\right)$, time $(2 \mathrm{~h})$, CLEA $(1.0 \mathrm{mg})$ and BPA concentration 372 (40 mg/L). The biodegradation efficiency obtained after the experiment was conducted thrice 373 was $98.4 \pm 1.2$.

\section{3.6. Reusability of CLEA in BPA biodegradation}

375 Laccase CLEA under the optimum conditions removed BPA from solutions while retaining 376 about $63 \pm 2.3 \%$ biodegradation efficiency after the 7 th cycle (Supplementary S12). The gradual

377 loss of enzymatic activity by the CLEA might be associated with mass-transfer limitations

\section{$378 \quad 4.0$ Conclusions}

Response surface methodology provided a unique mathematical/statistical model for both the preparation of laccase CLEA and its application in the removal of BPA. From this study, the optimum conditions for CLEA preparation resulting in the highest immobilization yield were ammonium sulphate $(60 \% \mathrm{v} / \mathrm{v})$, glutaraldehyde $(30 \mathrm{mM}), \mathrm{pH}(4.5)$, time $(6 \mathrm{~h})$ and temperature $\left(55^{\circ} \mathrm{C}\right)$ while the optimum conditions for BPA biodegradation using the CLEA were temperature $\left(55^{\circ} \mathrm{C}\right)$, time $(2 \mathrm{~h})$, CLEA (1.0 mg) and BPA concentration (40 mg/L). The thermodynamic and kinetic properties of the CLEA indicated the biocatalyst was thermally stable and resistant to heat inactivation. This property is necessary for biocatalysts of industrial importance. The laccase CLEA retained about $63 \pm 2.3 \%$ of BPA biodegradation efficiency after seven rounds of catalysis. The CLEA could be deployed in possible large-scale BPA removal and other futuristic biotechnological applications. 
390 Ethical Approval: Ethics approval not required for this study.

391

392 -Consent to Participate: Not applicable

393

394 -Consent to Publish: Not applicable

395

396

397

398

399

400

401

402

403

404

405

406

407

408

409

410

411

412

413

414

415
-Authors Contributions: Ademakinwa Adedeji Nelson carried out the Investigation, Writing, Conceptualization, Methodology, Software, Data curation, Writing- Original draft preparation.

-Funding: The author has no relevant financial or non-financial interests to disclose.

-Competing Interests: The author declares that there are no conflicts of interests

-Availability of data and materials: Yes 


\section{References}

[1] Giardina, P., Faraco, V., Pezzella, C., Piscitelli, A., Vanhulle, S. and Sannia, G. (2009). Laccases: a never-ending story. Cellular and Molecular Life Sciences, 67(3), 369385. doi:10.1007/s00018-009-0169-1

[2] Viswanath, B., Rajesh, B., Janardhan, A., Kumar, A.P. and Narasimha, G. (2014). Fungal Laccases and Their Applications in Bioremediation. Enzyme Research, 2014, 121. doi:10.1155/2014/163242

[3] Cabana, H., Jones, J.P. and Agathos, S.N. (2007). Preparation and characterization of cross-linked laccase aggregates and their application to the elimination of endocrine disrupting chemicals. Journal of Biotechnology, 132(1), 2331. doi:10.1016/j.jbiotec.2007.07.948

[4] Bosso, L. and Cristinzio, G. A. (2014). A comprehensive overview of bacteria and fungi used for pentachlorophenol biodegradation. Reviews in Environmental Science and Bio/Technology, 13(4), 387-427. doi:10.1007/s11157-014-9342-6

[5] Dekant, W. and Völkel, W. (2008). Human exposure to bisphenol A by biomonitoring: Methods, results and assessment of environmental exposures. Toxicology and Applied Pharmacology, 228(1), 114-134. doi:10.1016/j.taap.2007.12.008

[6] Bilal, M., Iqbal, H.M.N. and Barceló, D. (2019). Mitigation of bisphenol A using an array of laccase-based robust bio-catalytic cues - A review. Science of The Total Environment. doi:10.1016/j.scitotenv.2019.06.403

[7] Durán, N., Rosa, M.A., D’Annibale, A. and Gianfreda, L. (2002). Applications of laccases and tyrosinases (phenoloxidases) immobilized on different supports: a review. Enzyme and Microbial Technology, 31(7), 907-931. doi:10.1016/s0141-0229(02)00214-4

[8] Sheldon, R.A. (2007). Cross-linked enzyme aggregates (CLEA®s): stable and recyclable biocatalysts. Biochemical Society Transactions, 35(6), 15831587. doi:10.1042/bst0351583

[9] Cao ,L., van Rantwijk, F. and Sheldon, R.A. (2000). Cross-Linked Enzyme Aggregates: A Simple and Effective Method for the Immobilization of Penicillin Acylase. Organic Letters, 2(10), 1361-1364. doi:10.1021/o1005593x 
[10] Rich, J.O., Leathers, T.D., Anderson, A.M., Bischoff, K.M. and Manitchotpisit P. (2013). Laccases from Aureobasidium pullulans. Enzyme and Microbial Technology, 53(1), 33-37. doi:10.1016/j.enzmictec.2013.03.015

[11] Ademakinwa, A.N. and Agboola, F.K. (2016). Biochemical characterization and kinetic studies on a purified yellow laccase from newly isolated Aureobasidium pullulans NAC8 obtained from soil containing decayed plant matter. Journal of Genetic Engineering and Biotechnology, 14(1), 143-151. doi:10.1016/j.jgeb.2016.05.004

[12] Ademakinwa, A.N. and Agboola, F.K. (2015). Bioremediation of textile dye solutions, textile dye mixtures and textile effluents by laccase from Aureobasidium pullulans (de Bary) G. Arnaud (1918)(Fungi: Ascomycota). Brazilian Journal of Biological Sciences, 2(4), 253-262.

[13] Vršanská, M., Voběrková, S., Jiménez Jiménez, A., Strmiska, V. and Adam, V. (2017). Preparation and Optimisation of Cross-Linked Enzyme Aggregates Using Native Isolate White Rot Fungi Trametes versicolor and Fomes fomentarius for the Decolourisation of Synthetic Dyes. International Journal of Environmental Research and Public Health, 15(1), 23. doi:10.3390/ijerph15010023

[14] Ferreira, S., Duarte, A.P., Ribeiro, M.H.L., Queiroz, J.A. and Domingues, F.C. (2009). Response surface optimization of enzymatic hydrolysis of Cistus ladanifer and Cytisus striatus for bioethanol production. Biochemical Engineering Journal, 45(3), 192-200. doi:10.1016/j.bej.2009.03.012

[15] Ademakinwa, A.N. and Agboola, F.K. (2020). Some biochemical, catalytic, thermodynamic and kinetic properties of purified fructosyltransferase from wild and improved mutant-type Aureobasidium pullulans NAC8. Biocatalysis and Biotransformation, 1-12. doi:10.1080/10242422.2019.1671376

[16] Bradford, M.M. (1976). A rapid and sensitive method for the quantitation of microgram quantities of protein utilizing the principle of protein-dye binding. Analytical Biochemistry, 72(1-2), 248-254. doi:10.1016/0003-2697(76)90527-3

[17] Ademakinwa, A.N., Ayinla, Z.A., Omitogun, O.G. and Agboola, F.K. (2018) Preparation, characterization and optimization of cross-linked fructosyltransferase aggregates for the production of prebiotic fructooligosaccharides. BioTechnologia, 99(4), 417-434. https://doi.org/10.5114/bta.2018.79972 
[18] Melikoglu, M., Lin, C.S.K. and Webb, C. (2013). Kinetic studies on the multienzyme solution produced via solid state fermentation of waste bread by Aspergillus awamori. Biochem. Eng. J. 80 76-82. doi:10.1016/j.bej.2013.09.016

[19] Yang, J., Xu, X., Yang, X., Ye, X. and Lin, J. (2016). Cross-linked enzyme aggregates of Cerrena laccase: Preparation, enhanced $\mathrm{NaCl}$ tolerance and decolorization of Remazol Brilliant Blue Reactive. Journal of the Taiwan Institute of Chemical Engineers, 65, 1-7. doi:10.1016/j.jtice.2016.04.025

[20] Ramírez-Cavazos, L.I., Junghanns, C., Ornelas-Soto, N. (2014). Purification and Characterization of two thermostable laccases from Pycnoporus sanguineus and potential role in degradation of endocrine disrupting chemicals. Journal of Molecular Catalysis B: Enzymatic, 104, 32-42.

[21] Lassouane, F., Aït-Amar, H., Amrani, S. and Rodriguez-Couto, A. (2019). A promising laccase immobilization approach for Bisphenol A removal from aqueous solutions. Bioresour. Technol. doi:10.1016/j.biortech.2018.09.129

[22] Teerapatsakul, C., Parra, R., Keshavarz, T. and Chitradon, L. (2017). Repeated batch for dye degradation in an airlift bioreactor by laccase entrapped in copper alginate. International Biodeterioration and Biodegradation, 120, 5257. doi:10.1016/j.ibiod.2017.02.001

[23] Ademakinwa, A.N. and Agboola, F.K. (2019). Kinetic and thermodynamic investigations of cell-wall degrading enzymes produced by Aureobasidium pullulans via induction with orange peels: application in lycopene extraction. Prep. Biochem. Biotech. 49, 949-960. https://doi.10.1080/10826068.2019.1650375

[24] Ademakinwa, A.N. and Agunbiade, M.O. and Fagbohun, O. (2020). Biodegradation of cyanide in cassava wastewater using a novel thermodynamically-stable immobilized rhodanese. Preparative Biochemistry \& Biotechnology, 111. doi:10.1080/10826068.2020.1846053

[25] Ademakinwa, A.N., Agunbiade, M.O., Ayinla, Z.A. and Agboola, F.K. (2019). Optimization of aqueous two-phase partitioning of Aureobasidium pullulans a-amylase via response surface methodology and investigation of its thermodynamic and kinetic properties. International Journal of Biological Macromolecules. doi:10.1016/j.ijbiomac.2019.08.159

[26] Souza, P.M., Aliakbarian, B., Filho, E.X.F., Magalhães, P.O., Junior, A.P., Converti A. and Perego P. (2015). Kinetic and thermodynamic studies of a novel acid protease from 
Aspergillus foetidus. International Journal of Biological Macromolecules, 81, 17-21 (2015). doi:10.1016/j.ijbiomac.2015.07.043

[27] Saqib, A.A.N., Hassan, M., Khan, N.F, Baig S. (2010). Thermostability of crude endoglucanase from Aspergillus fumigatus grown under solid state fermentation (SSF) and submerged fermentation (SmF). Process Biochemistry, 45(5), 641-646 (2010). doi:10.1016/j.procbio.2009.12.011

[28] Gohel, S.D. and Singh, S.P. (2013). Characteristics and thermodynamics of a thermostable protease from a salt-tolerant alkaliphilic actinomycete. International Journal of Biological Macromolecules, 56, 20-27. doi:10.1016/j.ijbiomac.2013.01.028

[29] Schoevaart, R., Wolbers, M.W., Golubovic, M., Ottens, M., Kieboom, A.P.G., van Rantwijk, F. and Sheldon, R.A. (2004).Preparation, optimization, and structures of crosslinked enzyme aggregates (CLEAs). Biotechnology and Bioengineering, 87(6), 754762. doi:10.1002/bit.20184

[30] Asadgol, Z., Forootanfar, H. and Rezaei, S. (2014). Removal of phenol and bisphenol-A catalyzed by laccase in aqueous solution. J Environ Health Sci Engineer 12, 93. https://doi.org/10.1186/2052-336X-12-93

525

526

527

528

529

530

531

532

533

534

535 


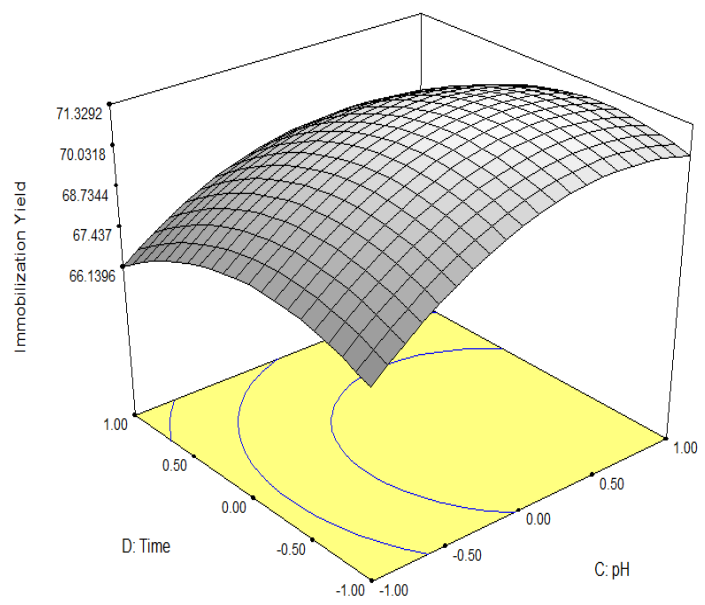

546 Fig.1. Response surface plots for the preparation of CLEA. Effect of time and pH (A). The Figures 547 indicating the effects of glutaraldehyde and precipitant $(\mathrm{B})$ precipitant and $\mathrm{pH}(\mathrm{C})$ temperature and 548 time (D) and temperature and $\mathrm{pH}$ on the immobilization yield of the laccase CLEA are shown in the 549 supplementary section.

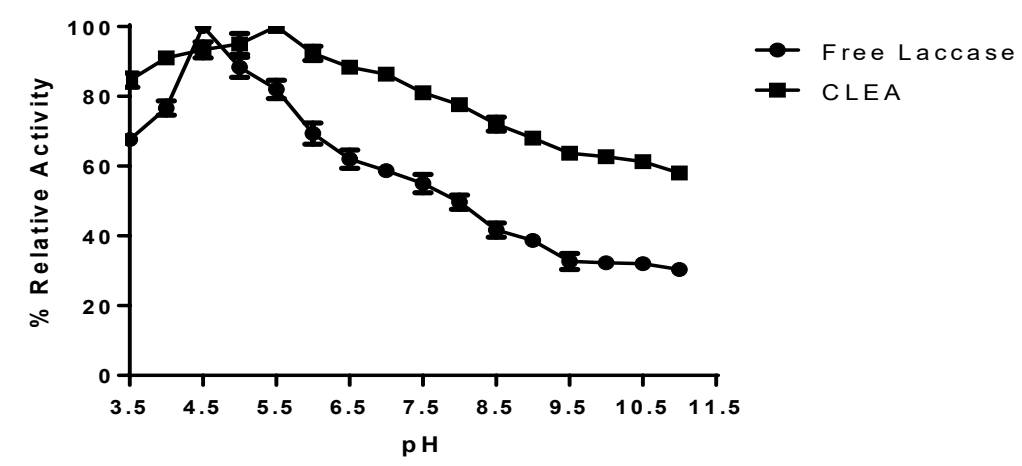

553 Fig. 2. Effect of $\mathrm{pH}$ on free an immobilized laccase 


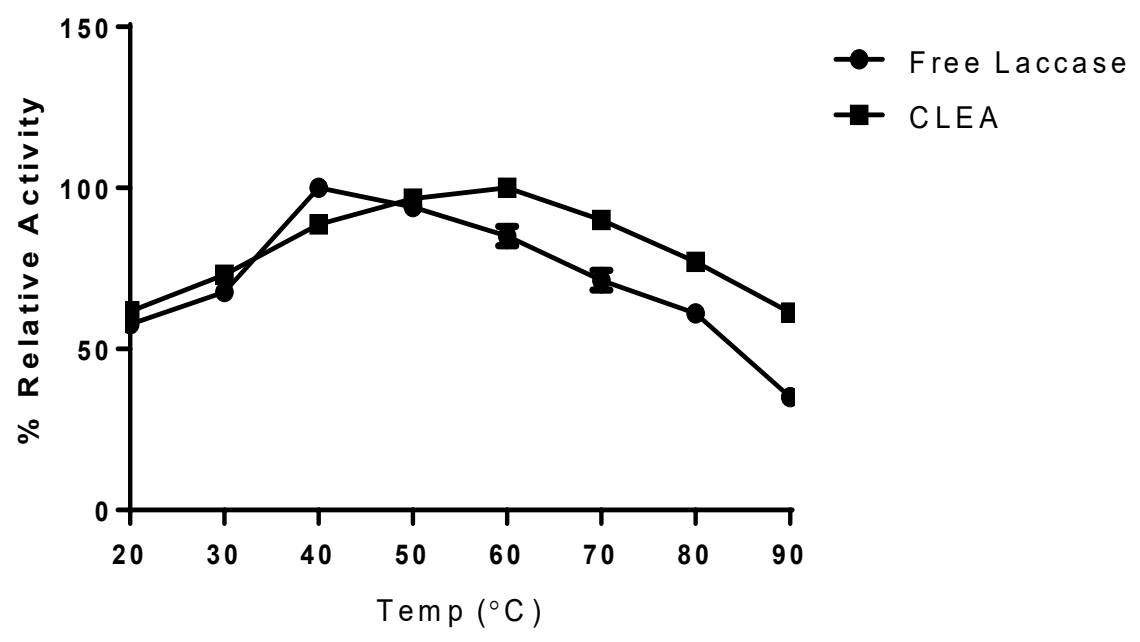

555 Fig. 3. Effect of temperature on free and immobilized laccase

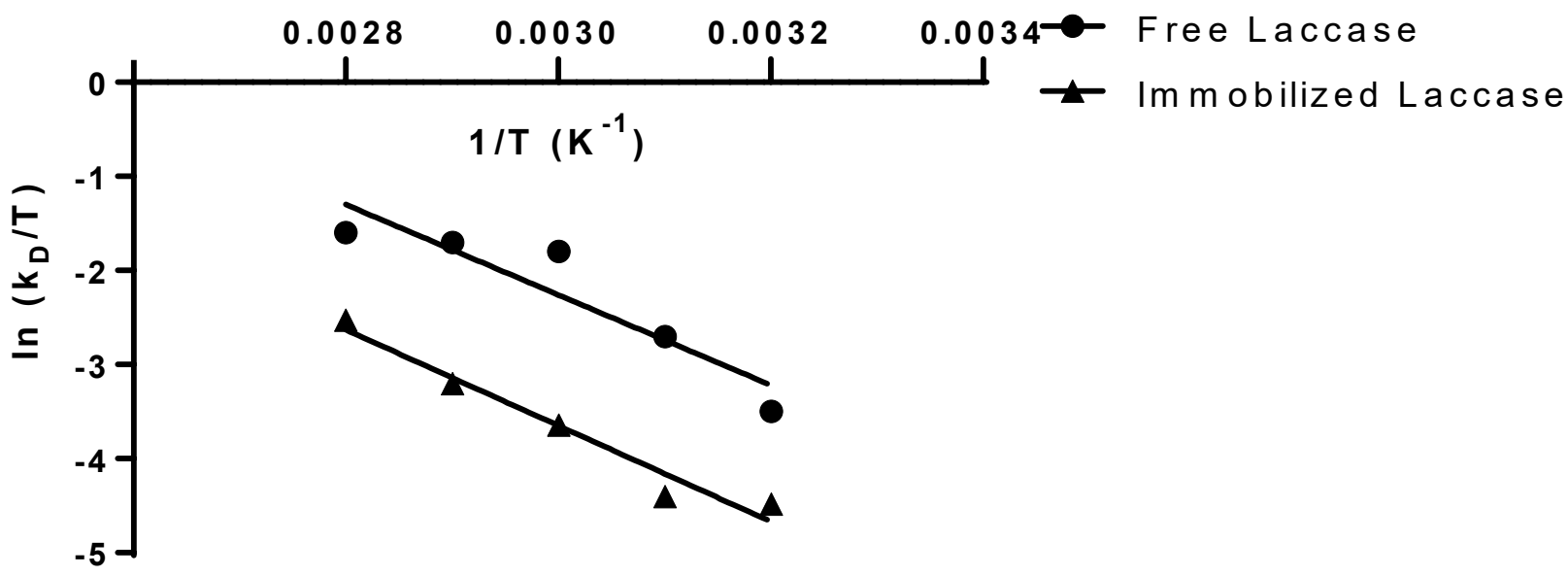

Fig. 4. Arrhenius-type plot to estimate the activation energy of thermal denaturation ( $\left.E_{d}^{*}\right)$ for free and 560 immobilized laccase 


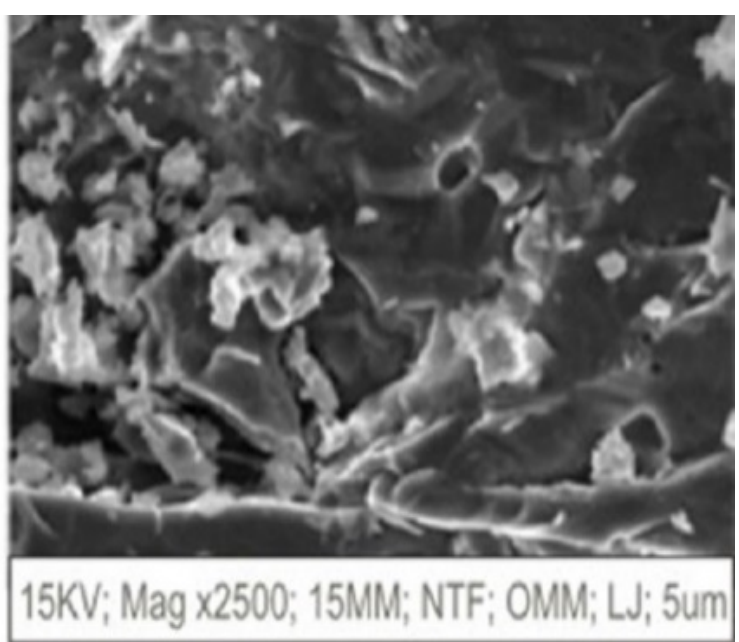

564

565 566

567

568

569

570

571

572

573

574

575

576

577

578

579

580

581

582

583

584

585

Fig. 5. Scanning electron microscopy of the laccase CLEA 
Table 1: Regression analysis and analysis of variance (ANOVA) table for the immobilization yield (\%) of 587 laccase CLEA preparation

\begin{tabular}{|c|l|l|l|l|l|l|}
\hline Source & Sum of squares & df & Mean square & F-value & $\begin{array}{l}\text { p-value } \\
\text { prob }>\text { F }\end{array}$ & \\
\hline Model & 1168.20 & 20 & 58.41 & 36.31 & $<0.0001$ & Significant \\
\hline$X_{1}$ & 680.29 & 1 & 680.29 & 422.85 & $<0.0001$ & Significant \\
\hline$X_{2}$ & 14.02 & 1 & 14.02 & 8.71 & 0.0062 & Significant \\
\hline$X_{3}$ & 71.66 & 1 & 71.66 & 44.54 & 0.0002 & Significant \\
\hline$X_{4}$ & 29.74 & 1 & 29.74 & 18.48 & 0.0024 & Significant \\
\hline$X_{5}$ & 9.36 & 1 & 9.36 & 5.82 & $<0.0001$ & Significant \\
\hline$X_{1} X_{2}$ & 136.11 & 1 & 136.11 & 84.60 & 0.043 & Significant \\
\hline$X_{1} X_{3}$ & 7.42 & 1 & 7.42 & 4.61 & $<0.0001$ & Significant \\
\hline$X_{1} X_{4}$ & 137.32 & 1 & 137.32 & 85.36 & $<0.0001$ & Significant \\
\hline$X_{1} X_{5}$ & 107.19 & 1 & 107.19 & 66.63 & 0.0003 & Significant \\
\hline$X_{2} X_{3}$ & 26.79 & 1 & 26.79 & 16.65 & 0.004 & Significant \\
\hline$X_{2} X_{4}$ & 6.83 & 1 & 6.83 & 4.25 & 0.2499 & Not Significant \\
\hline$X_{2} X_{5}$ & 2.27 & 1 & 2.27 & 1.41 & 0.0007 & Significant \\
\hline$X_{3} X_{4}$ & 23.15 & 1 & 23.15 & 14.39 & 0.1036 & Not Significant \\
\hline$X_{3} X_{5}$ & 4.54 & 1 & 4.54 & 2.82 & 0.2527 & Not Significant \\
\hline$X_{4} X_{5}$ & 2.19 & 1 & 2.19 & 1.36 & 0.0276 & Significant \\
\hline$X_{1}^{2}$ & 8.66 & 1 & 8.66 & 5.38 & 0.7915 & Not Significant \\
\hline$X_{2}^{2}$ & 0.11 & 1 & 0.11 & 0.071 & 0.1775 & Not Significant \\
\hline$X_{3}^{2}$ & 3.07 & 1 & 3.07 & 1.91 & 0.0930 & Not Significant \\
\hline$X_{4}^{2}$ & 4.91 & 1 & 4.91 & 3.05 & 0.2859 & Not Significant \\
\hline$X_{5}^{2}$ & 1.90 & 1 & 1.90 & 1.18 & & \\
\hline Residual & 46.66 & 29 & 1.61 & & & \\
\hline Lack of fit & 46.66 & 22 & 2.12 & & & \\
\hline Pure error & 0.00 & 7 & 0.00 & & & \\
\hline Cor Total & 1214.86 & 49 & & & & \\
\hline
\end{tabular}


Table 2. Summary of the kinetic and thermodynamic parameters for free and immobilized laccase

\begin{tabular}{|c|c|c|c|c|c|c|}
\hline $\begin{array}{c}\boldsymbol{T} \\
(\boldsymbol{K})\end{array}$ & $k_{d}\left(h^{-1}\right)$ & $\begin{array}{l}t_{1 / 2} \\
(h)\end{array}$ & $\begin{array}{c}\boldsymbol{E}_{\boldsymbol{d}} \\
(\mathrm{kJ} / \mathrm{mol} / \mathrm{K})\end{array}$ & $\begin{array}{c}\Delta H_{d}^{*} \\
(\mathrm{~kJ} / \mathrm{mol})\end{array}$ & $\begin{array}{c}\Delta G_{d}^{*} \\
(\mathrm{~kJ} / \mathrm{mol})\end{array}$ & $\begin{array}{c}\Delta S_{d}^{*} \\
\mathrm{~J} / \mathrm{mol} / \mathbf{K}\end{array}$ \\
\hline 40 & $\begin{array}{c}\# 0.0317 \\
\boldsymbol{R}^{\mathbf{2}}=\mathbf{0 . 9 6} \\
* 0.0113 \\
\boldsymbol{R}^{\mathbf{2}}=\mathbf{0 . 9 4}\end{array}$ & $\begin{array}{l}\# 21.8 \\
* 61.1\end{array}$ & $\begin{array}{c}\# 39.9 \\
\boldsymbol{R}^{\mathbf{2}}=\mathbf{0 . 8 6}\end{array}$ & *39.8 & $* 88.5$ & *-155.6 \\
\hline 50 & $\begin{array}{c}\# 0.0645 \\
\boldsymbol{R}^{2}=\mathbf{0 . 9 8} \\
* 0.0128 \\
\boldsymbol{R}^{2}=\mathbf{0 . 9 5}\end{array}$ & $\begin{array}{l}\# 10.8 \\
* 54.1\end{array}$ & $\begin{array}{c}* 42.4 \\
\boldsymbol{R}^{2}=\mathbf{0 . 9 6}\end{array}$ & $\begin{array}{l}\# 37.2 \\
* 39.7\end{array}$ & $\begin{array}{l}\# 88.6 \\
* 91.0\end{array}$ & $\begin{array}{l}\#-159.1 \\
*_{-158.8}\end{array}$ \\
\hline 60 & $\begin{array}{c}\# 0.1718 \\
\boldsymbol{R}^{2}=\mathbf{0 . 9 8} \\
* 0.026 \\
\boldsymbol{R}^{2}=\mathbf{0 . 9 4}\end{array}$ & $\begin{array}{l}\# 4.0 \\
* 26.3\end{array}$ & & $\begin{array}{l}\# 37.1 \\
* 39.6\end{array}$ & $\begin{array}{l}\# 86.7 \\
* 91.9\end{array}$ & $\begin{array}{l}\#-149.0 \\
{ }^{*}-157.1\end{array}$ \\
\hline 70 & $\begin{array}{c}\# 0.1822 \\
\boldsymbol{R}^{2}=\mathbf{0 . 9 9} \\
*^{0} 0.0401 \\
\boldsymbol{R}^{2}=\mathbf{0 . 9 4}\end{array}$ & $\begin{array}{l}\# 3.8 \\
* 17.3\end{array}$ & & $\begin{array}{l}\# 37.0 \\
* 39.6\end{array}$ & $\begin{array}{l}\# 89.3 \\
* 93.6\end{array}$ & $\begin{array}{l}\#-152.5 \\
{ }^{*}-157.4\end{array}$ \\
\hline 80 & $\begin{array}{c}\# 0.1955 \\
\boldsymbol{R}^{2}=\mathbf{0 . 8 9} \\
* 0.0791 \\
\boldsymbol{R}^{2}=\mathbf{0 . 9 7}\end{array}$ & $\begin{array}{l}\# 3.5 \\
* 8.8\end{array}$ & & $* 39.5$ & $\begin{array}{l}\# 91.7 \\
* 94.4\end{array}$ & $\begin{array}{l}\#-155.0 \\
*-155.5\end{array}$ \\
\hline
\end{tabular}

600

601

602

603

604

605

606

607

608

609

610

611 612

\#- Free enzyme

* CLEA 


\begin{tabular}{|l|l|l|l|l|l|l|}
\hline & & & & & prob $>$ F & \\
\hline Model & 16877.51 & 14 & 1205.54 & 34.56 & $<0.0001$ & Significant \\
\hline A-BPA & 11530.10 & 1 & 11530.10 & 330.56 & $<0.0001$ & Significant \\
\hline B-Time & 75.57 & 1 & 75.57 & 2.17 & 0.1617 & \\
\hline C-Temp & 1735.02 & 1 & 1735.02 & 49.74 & $<0.0001$ & Significant \\
\hline D-CLEA & 826.26 & 1 & 826.26 & 23.69 & 0.0002 & Significant \\
\hline A2 & 360.85 & 1 & 360.85 & 10.35 & 0.0058 & Significant \\
\hline B2 & 439.98 & 1 & 439.98 & 12.61 & 0.0029 & Significant \\
\hline C2 & 42.93 & 1 & 42.93 & 1.23 & 0.2847 & \\
\hline D2 & 1940.95 & 1 & 1940.95 & 55.65 & $<0.0001$ & Significant \\
\hline AB & 27.28 & 1 & 27.28 & 0.78 & 0.3905 & \\
\hline AC & 97.71 & 1 & 97.71 & 2.80 & 0.1149 & \\
\hline AD & 224.37 & 1 & 224.37 & 6.43 & 0.0228 & \\
\hline BC & 35.18 & 1 & 35.18 & 1.01 & 0.3312 & \\
\hline BD & 4.17 & 1 & 4.17 & 0.12 & 0.7342 & \\
\hline CD & 30.24 & 1 & 30.24 & 0.87 & 0.3665 & \\
\hline Residual & 523.20 & 15 & 34.88 & & & \\
\hline Lack of fit & 523.20 & 10 & 52.32 & & & \\
\hline Pure error & 0.000 & 5 & & & & \\
\hline Cor Total & 17400.71 & 29 & & & & \\
\hline
\end{tabular}

614 Std.Dev $=5.91 ; R^{2}=0.97 ;$ Adj $R^{2}=0.94 ; C . V .=11.39 ;$ Adeq Precision $=20.99$

615

616

617

618

619

620

621

622

623

624

625

626

627

628

629 
630 S1 Central composite rotatable experimental design variables for the optimization of immobilization yield 631 of laccase CLEA preparation

$\begin{array}{cccccc}\text { Precipitant } & \text { Glutaraldehyde } & \mathrm{pH} & \text { Time } & \text { Temperature } & \text { Immobilization Yield } \\ \text { Conc. (v/v) } & (\mathrm{mM}) & & (\mathrm{h}) & { }^{\circ} \mathrm{C} & (\%) \\ \left(x_{1}\right) & \left(x_{2}\right) & \left(x_{3}\right) & \left(x_{4}\right) & \left(x_{5}\right)\end{array}$

\begin{tabular}{|c|c|c|c|c|c|c|c|}
\hline & $\left(x_{1}\right)$ & $\left(x_{2}\right)$ & $\left(x_{3}\right)$ & $\left(x_{4}\right)$ & $\left(x_{5}\right)$ & & \\
\hline & & & & & & Experimental & Observed \\
\hline 1 & $-1(50)$ & $-1(30)$ & $-1(3.5)$ & $-1(4)$ & $-1(30)$ & 67.87 & 67.52 \\
\hline 2 & $1(65)$ & $-1(30)$ & $-1(3.5)$ & $-1(4)$ & $-1(30)$ & 60.72 & 60.15 \\
\hline 3 & $-1(50)$ & $1(70)$ & $-1(3.5)$ & $-1(4)$ & $-1(30)$ & 68.58 & 68.37 \\
\hline 4 & $1(65)$ & $1(70)$ & $-1(3.5)$ & $-1(4)$ & $-1(30)$ & 62.15 & 62.85 \\
\hline 5 & $-1(50)$ & $-1(30)$ & $1(5.5)$ & $-1(4)$ & $-1(30)$ & 54.23 & 57.34 \\
\hline 6 & $1(65)$ & $-1(30)$ & $1(5.5)$ & $-1(4)$ & $-1(30)$ & 62.15 & 61.50 \\
\hline 7 & $-1(50)$ & $1(70)$ & $1(5.5)$ & $-1(4)$ & $-1(30)$ & 70.73 & 71.84 \\
\hline 8 & $1(65)$ & $1(70)$ & $1(5.5)$ & $-1(4)$ & $-1(30)$ & 67.87 & 65.25 \\
\hline 9 & $-1(50)$ & $-1(30)$ & $-1(3.5)$ & $1(8)$ & $-1(30)$ & 67.87 & 68.54 \\
\hline 10 & $1(65)$ & $-1(30)$ & $-1(3.5)$ & $1(8)$ & $-1(30)$ & 59.30 & 57.96 \\
\hline 11 & $-1(50)$ & $1(70)$ & $-1(3.5)$ & $1(8)$ & $-1(30)$ & 68.30 & 67.51 \\
\hline 12 & $1(65)$ & $1(70)$ & $-1(3.5)$ & $1(8)$ & $-1(30)$ & 59.30 & 58.58 \\
\hline 13 & $-1(50)$ & $-1(30)$ & $1(5.5)$ & $1(8)$ & $-1(30)$ & 70.94 & 69.92 \\
\hline 14 & $1(65)$ & $-1(30)$ & $1(5.5)$ & $1(8)$ & $-1(30)$ & 57.15 & 58.08 \\
\hline 15 & $-1(50)$ & $1(70)$ & $1(5.5)$ & $1(8)$ & $-1(30)$ & 70.94 & 69.73 \\
\hline 16 & $1(65)$ & $1(70)$ & $1(5.5)$ & $1(8)$ & $-1(30)$ & 57.15 & 59.74 \\
\hline 17 & $-1(50)$ & $-1(30)$ & $-1(3.5)$ & $-1(4)$ & $1(55)$ & 67.87 & 66.55 \\
\hline 18 & $1(65)$ & $-1(30)$ & $-1(3.5)$ & $-1(4)$ & $1(55)$ & 60.72 & 60.68 \\
\hline 19 & $-1(50)$ & $1(70)$ & $-1(3.5)$ & $-1(4)$ & $1(55)$ & 68.58 & 67.16 \\
\hline 20 & $1(65)$ & $1(70)$ & $-1(3.5)$ & $-1(4)$ & $1(55)$ & 62.15 & 63.14 \\
\hline 21 & $-1(50)$ & $-1(30)$ & $1(5.5)$ & $-1(4)$ & $1(55)$ & 71.01 & 70.53 \\
\hline 22 & $1(65)$ & $-1(30)$ & $1(5.5)$ & $-1(4)$ & $1(55)$ & 62.15 & 63.30 \\
\hline 23 & $-1(50)$ & $1(70)$ & $1(5.5)$ & $-1(4)$ & $1(55)$ & 70.95 & 72.19 \\
\hline
\end{tabular}




\begin{tabular}{|c|c|c|c|c|c|c|c|}
\hline 24 & $1(65)$ & $1(70)$ & $1(5.5)$ & $-1(4)$ & $1(55)$ & 67.87 & 67.11 \\
\hline 25 & $-1(50)$ & $-1(30)$ & $-1(3.5)$ & $1(8)$ & $1(55)$ & 67.94 & 68.74 \\
\hline 26 & $1(65)$ & $-1(30)$ & $-1(3.5)$ & $1(8)$ & $1(55)$ & 59.30 & 59.47 \\
\hline 27 & $-1(50)$ & $1(70)$ & $-1(3.5)$ & $1(8)$ & $1(55)$ & 66.08 & 67.27 \\
\hline 28 & $1(65)$ & $1(70)$ & $-1(3.5)$ & $1(8)$ & $1(55)$ & 59.30 & 59.45 \\
\hline 29 & $-1(50)$ & $-1(30)$ & $1(5.5)$ & $1(8)$ & $1(55)$ & 70.95 & 71.48 \\
\hline 30 & $1(65)$ & $-1(30)$ & $1(5.5)$ & $1(8)$ & $1(55)$ & 62.15 & 61.15 \\
\hline 31 & $-1(50)$ & $1(70)$ & $1(5.5)$ & $1(8)$ & $1(55)$ & 70.95 & 71.06 \\
\hline 32 & $1(65)$ & $1(70)$ & $1(5.5)$ & $1(8)$ & $1(55)$ & 62.30 & 62.58 \\
\hline 33 & $-2.38(40)$ & $0(30)$ & $0(4.5)$ & $0(6)$ & $0(45)$ & 70.88 & 71.48 \\
\hline 34 & $2.38(70)$ & $0(30)$ & $0(4.5)$ & $0(6)$ & $0(45)$ & 52.87 & 52.63 \\
\hline 35 & $0(60)$ & -2.38 & $0(4.5)$ & $0(6)$ & $0(45)$ & 66.44 & 67.49 \\
\hline 36 & $0(60)$ & 2.38 & $0(4.5)$ & $0(6)$ & $0(45)$ & 70.88 & 70.19 \\
\hline 37 & $0(60)$ & $0(30)$ & $-2.38(3.0)$ & $0(6)$ & $0(45)$ & 58.58 & 58.95 \\
\hline 38 & $0(60)$ & $0(30)$ & $2.38(7.0)$ & $0(6)$ & $0(45)$ & 65.08 & 65.07 \\
\hline 39 & $0(60)$ & $0(30)$ & $0(4.5)$ & $-2.38(2)$ & $0(45)$ & 63.58 & 65.02 \\
\hline 40 & $0(60)$ & $0(30)$ & $0(4.5)$ & $2.38(10)$ & $0(45)$ & 62.15 & 61.08 \\
\hline 41 & $0(60)$ & $0(30)$ & $0(4.5)$ & $0(6)$ & $-2.38(20)$ & 64.30 & 65.87 \\
\hline 42 & $0(60)$ & $0(30)$ & $0(4.5)$ & $0(6)$ & $2.38(70)$ & 69.30 & 68.08 \\
\hline 43 & $0(60)$ & $0(30)$ & $0(4.5)$ & $0(6)$ & $0(45)$ & 73.21 & 72.89 \\
\hline 44 & $0(60)$ & $0(30)$ & $0(4.5)$ & $0(6)$ & $0(45)$ & 72.98 & 73.12 \\
\hline 45 & $0(60)$ & $0(30)$ & $0(4.5)$ & $0(6)$ & $0(45)$ & 73.66 & 72.99 \\
\hline 46 & $0(60)$ & $0(30)$ & $0(4.5)$ & $0(6)$ & $0(45)$ & 74.21 & 73.87 \\
\hline 47 & $0(60)$ & $0(30)$ & $0(4.5)$ & $0(6)$ & $0(45)$ & 73.00 & 72.67 \\
\hline 48 & $0(60)$ & $0(30)$ & $0(4.5)$ & $0(6)$ & $0(45)$ & 72.86 & 73.10 \\
\hline 49 & $0(60)$ & $0(30)$ & $0(4.5)$ & $0(6)$ & $0(45)$ & 72.87 & 73.03 \\
\hline 50 & $0(60)$ & $0(30)$ & $0(4.5)$ & $0(6)$ & $0(45)$ & 73.00 & 72.65 \\
\hline
\end{tabular}


634 S2: Central composite rotatable experimental design variables for the optimization of biodegradation of 635 BPA by laccase CLEA

$\begin{array}{ccccc}\text { BPA } & \text { Time } & \text { Temp } & \text { CLEA } & \text { Biodegradation } \\ (\mathrm{mg} / \mathrm{L}) & (\mathrm{h}) & (\mathrm{C}) & (\mathrm{mg}) & (\%) \\ \left(x_{1}\right) & \left(x_{2}\right) & \left(x_{3}\right) & \left(x_{4}\right) & \end{array}$

Experimental Observed

\begin{tabular}{|c|c|c|c|c|c|c|}
\hline 1 & $1(40)$ & $-1(2)$ & $1(50)$ & $-1(1.0)$ & 73.8 & 70.0 \\
\hline 2 & $-2(25)$ & $0(3)$ & $0(40)$ & $0(1.5)$ & 31.5 & 26.2 \\
\hline 3 & $1(40)$ & $1(4)$ & $1(50)$ & $1(2.0)$ & 64.4 & 65.1 \\
\hline 4 & $0(35)$ & $2(5)$ & $-1(30)$ & $0(1.5)$ & 18.1 & 16.1 \\
\hline 5 & $-1(30)$ & $1(4)$ & $0(40)$ & $-1(1.0)$ & 87.0 & 91.7 \\
\hline 6 & $1(40)$ & $-1(2)$ & $-1(30)$ & $1(2.0)$ & 35.7 & 38.1 \\
\hline 7 & $1(40)$ & $-1(2)$ & $-1(30)$ & $-1(1.0)$ & 99.9 & 92.7 \\
\hline 8 & $-1(30)$ & $-1(2)$ & $-1(30)$ & $-1(1.0)$ & 26.5 & 33.8 \\
\hline 9 & $2(45)$ & $0(3)$ & $1(50)$ & $0(1.5)$ & 56.9 & 52.5 \\
\hline 10 & $0(35)$ & $0(3)$ & $0(40)$ & $0(1.5)$ & 20.8 & 23.7 \\
\hline 11 & $0(35)$ & $0(3)$ & $0(40)$ & $0(1.5)$ & 56.2 & 49.5 \\
\hline 12 & $0(35)$ & $0(3)$ & $0(40)$ & $0(1.5)$ & 17.5 & 15.3 \\
\hline 13 & $0(35)$ & $0(3)$ & $0(40)$ & $-2(0.5)$ & 70.9 & 68.6 \\
\hline 14 & $1(40)$ & $-1(2)$ & $0(40)$ & $1(2.0)$ & 27.8 & 30.8 \\
\hline 15 & $0(35)$ & $-2(1)$ & $1(50)$ & $0(1.5)$ & 63.6 & 71.1 \\
\hline 16 & $-1(30)$ & $-1(2)$ & $0(40)$ & $1(2.0)$ & 28.4 & 27.1 \\
\hline 17 & $0(35)$ & $0(3)$ & $1(50)$ & $2(2.5)$ & 90.3 & 95.0 \\
\hline 18 & $0(35)$ & $0(3)$ & $0(40)$ & $0(1.5)$ & 10.5 & 7.3 \\
\hline 19 & $0(35)$ & $0(3)$ & $2(60)$ & $0(1.5)$ & 52.1 & 53.0 \\
\hline 20 & $1(40)$ & $1(4)$ & $0(40)$ & $-1(1.0)$ & 45.7 & 46.1 \\
\hline 21 & $-1(30)$ & $-1(2)$ & $1(50)$ & $1(2.0)$ & 34.0 & 43.7 \\
\hline 22 & $1(40)$ & $1(4)$ & $-1(30)$ & $1(2.0)$ & 85.8 & 77.8 \\
\hline 23 & $-1(30)$ & $1(4)$ & $1(50)$ & $1(2.0)$ & 42.8 & 43.6 \\
\hline
\end{tabular}




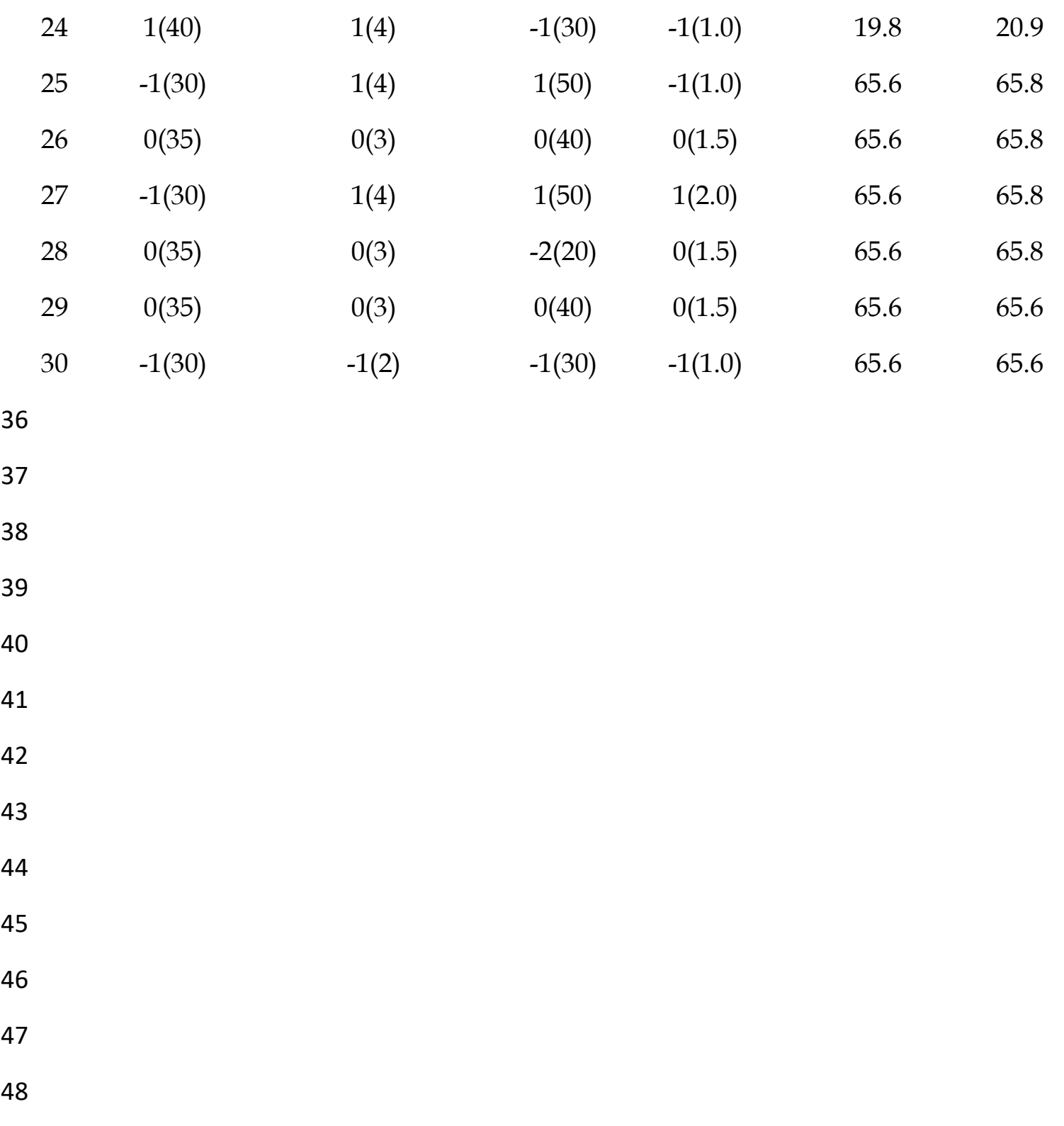




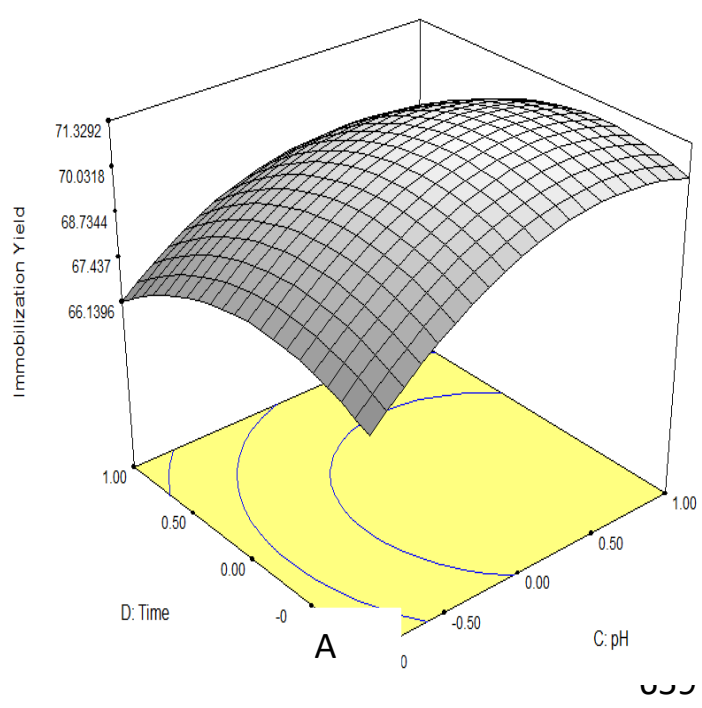

660

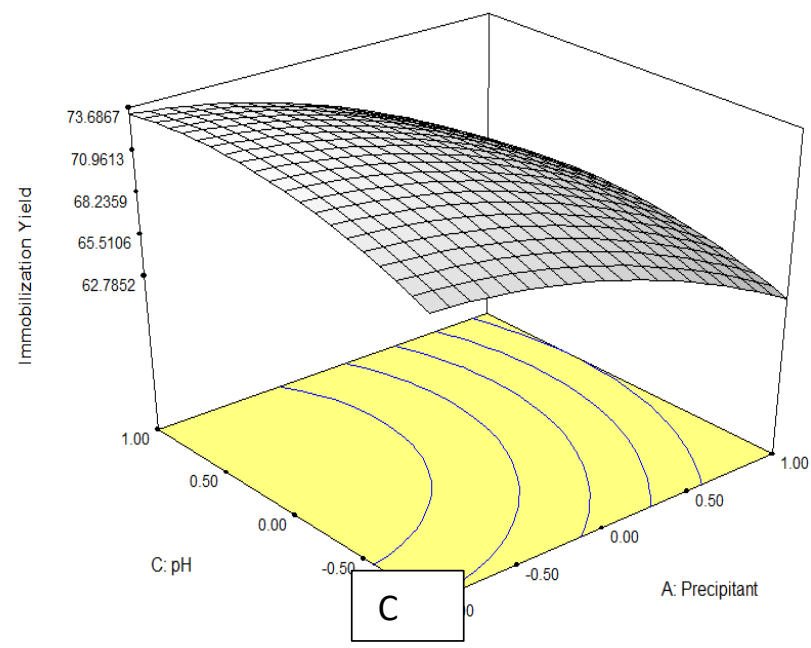

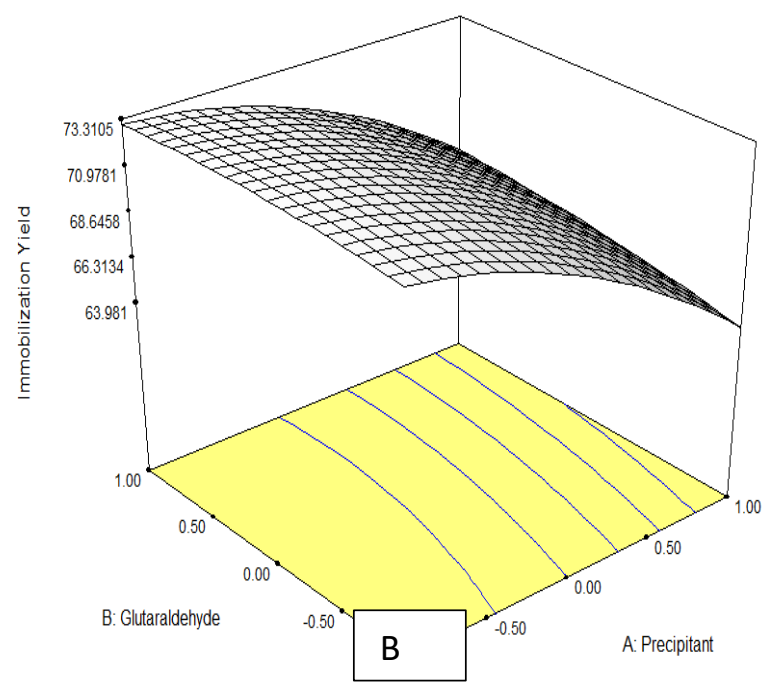

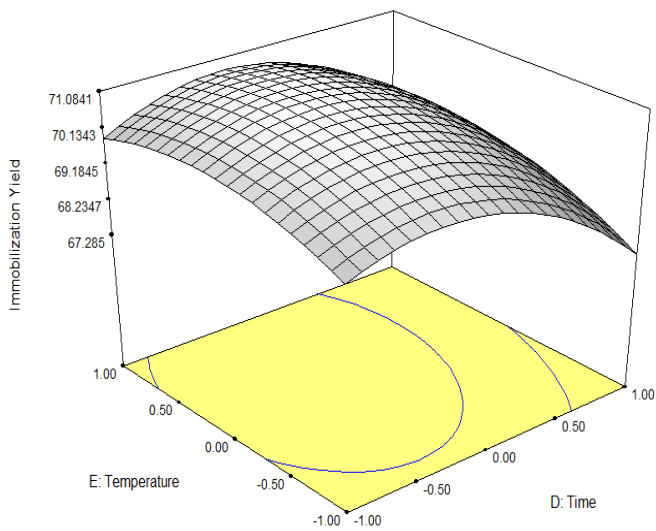

D

661

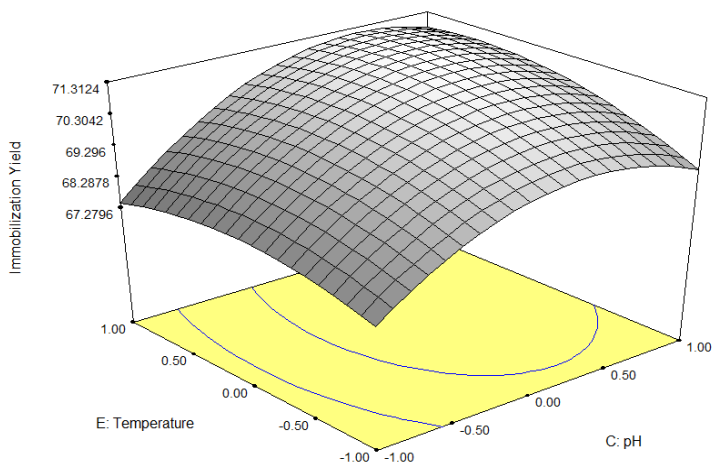

E 
S3: Response surface plots for the preparation of CLEA. Effect of time and $\mathrm{pH}$ (A) glutaraldehyde and precipitant (B) precipitant and $\mathrm{pH}(\mathrm{C})$ temperature and time (D) and temperature and $\mathrm{pH}$ on the 665 immobilization yield of the laccase CLEA

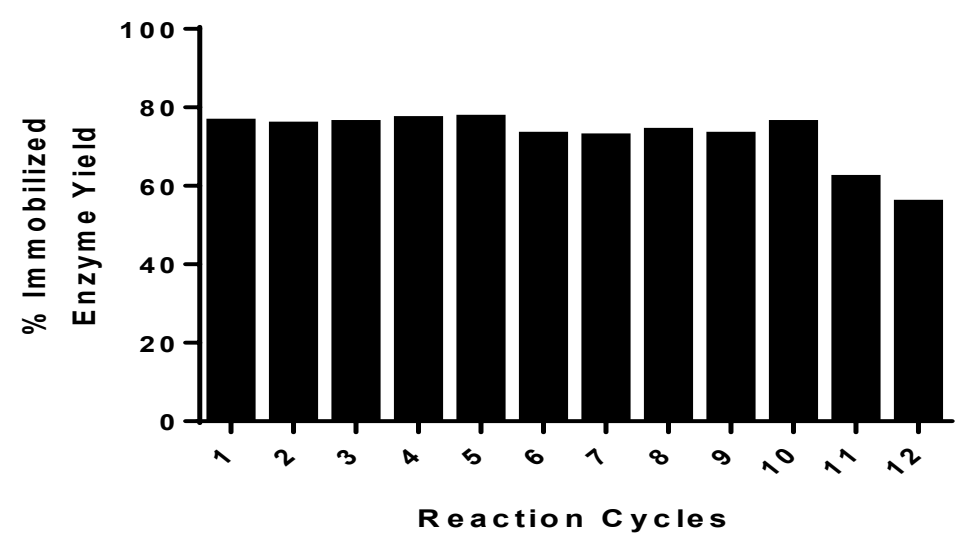

667 S4: Reusability of CLEA

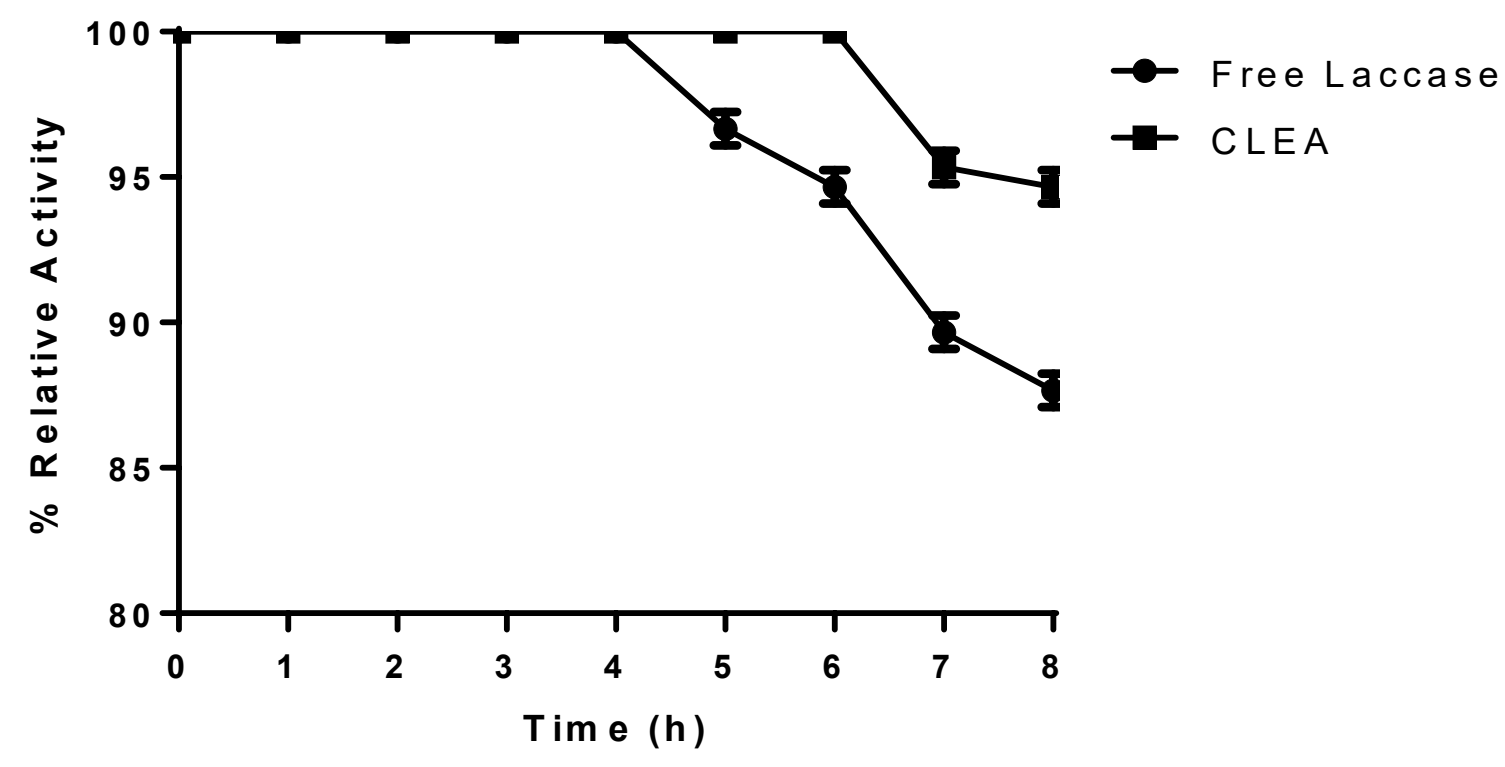

669 S5: $\mathrm{pH}$ stability of free and immobilized laccase 


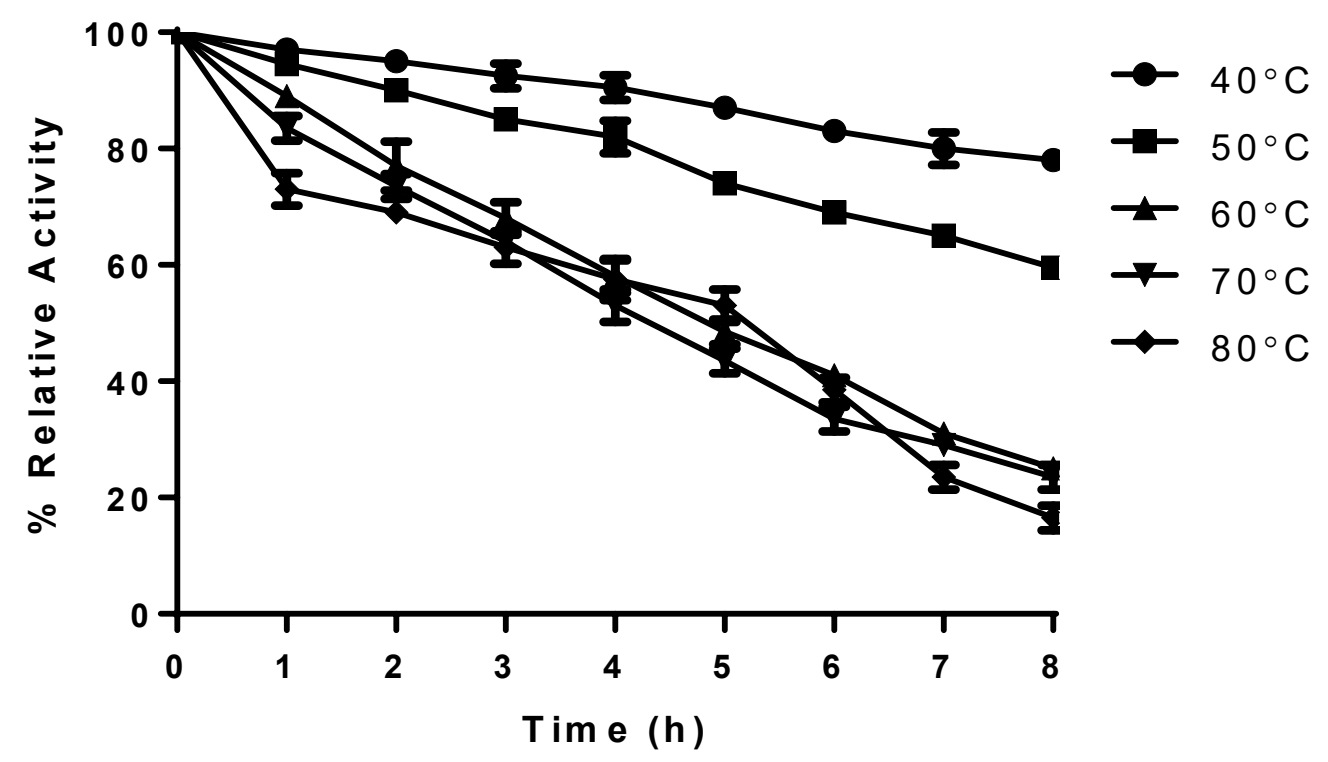

670

671 S6: Thermostability of free laccase

672

Time $(h)$

67

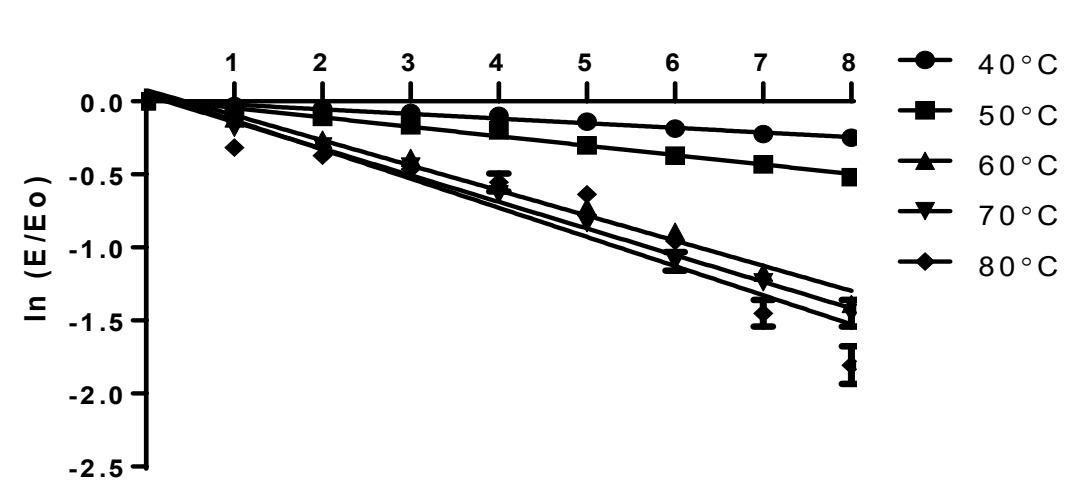

675

S7: Plot of In (E/Eo) against 1/T for free laccase

676

677

678

679

680

681 


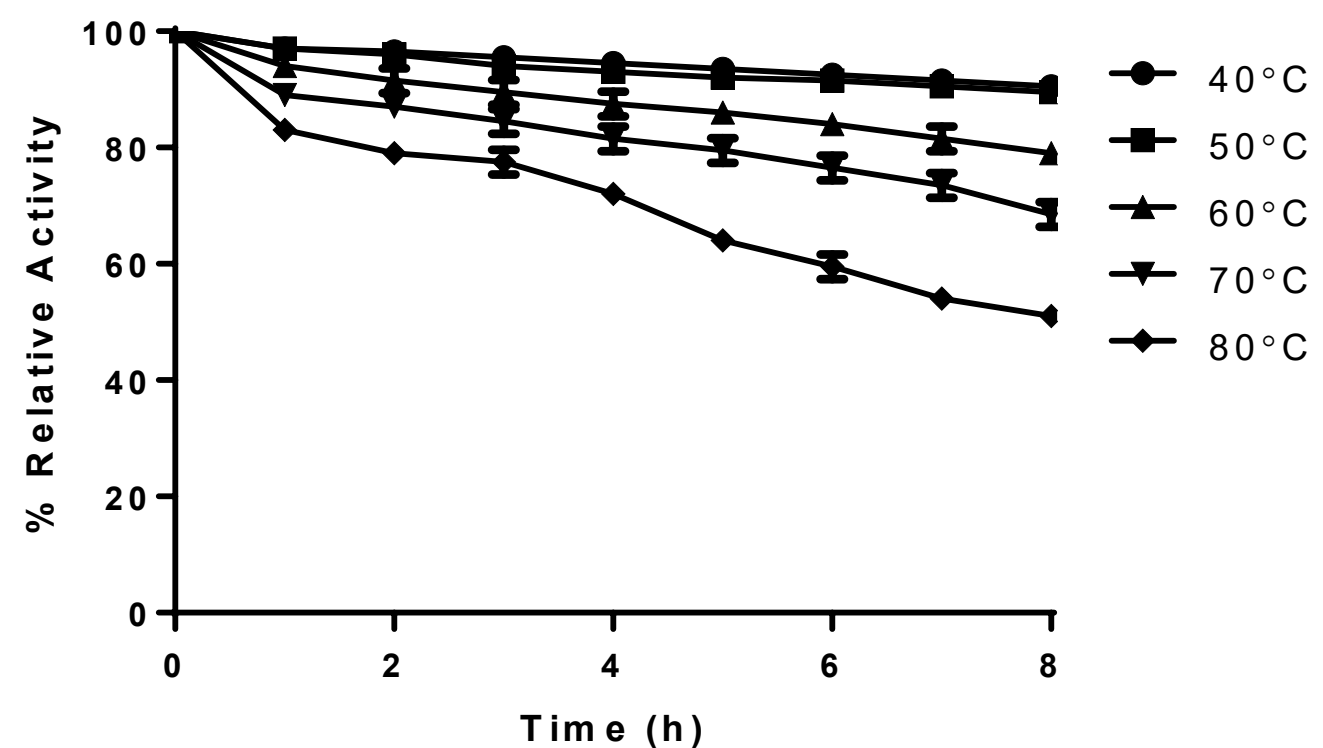

684

685

686

S8: Thermostability of laccase CLEA

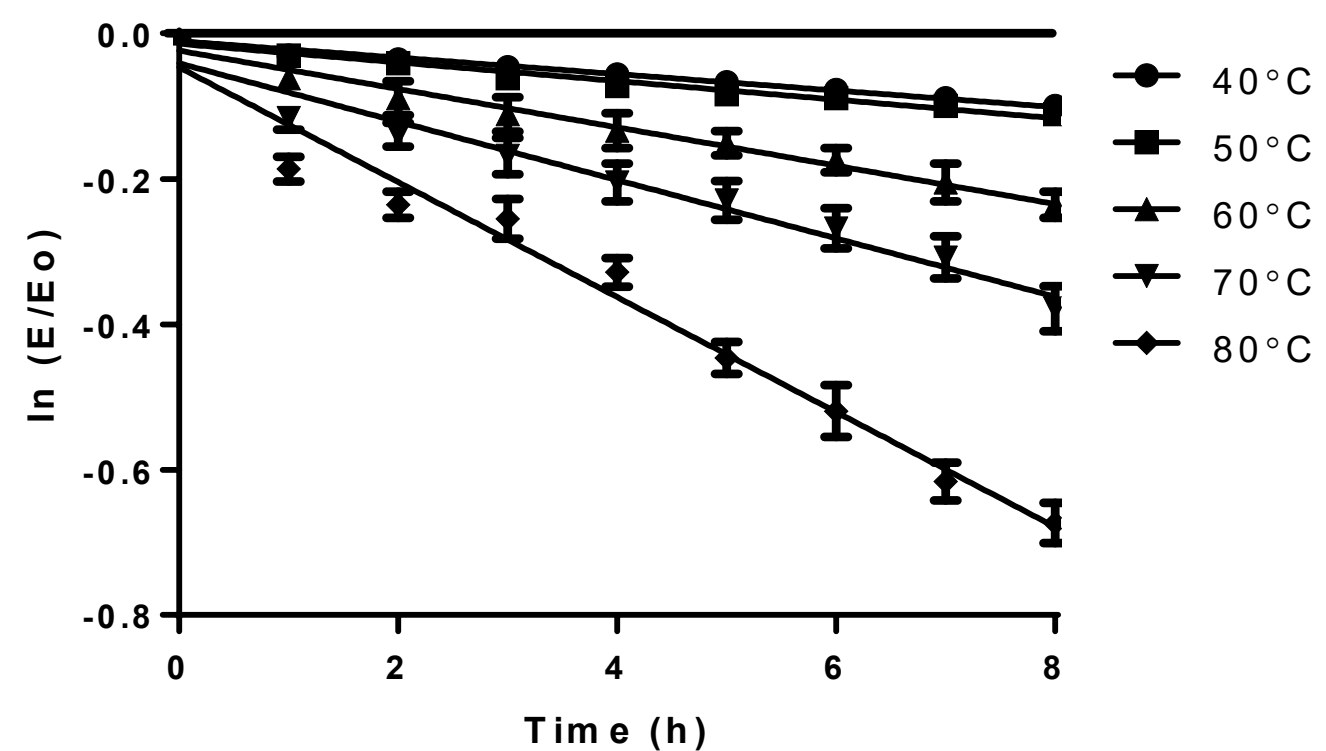

687 


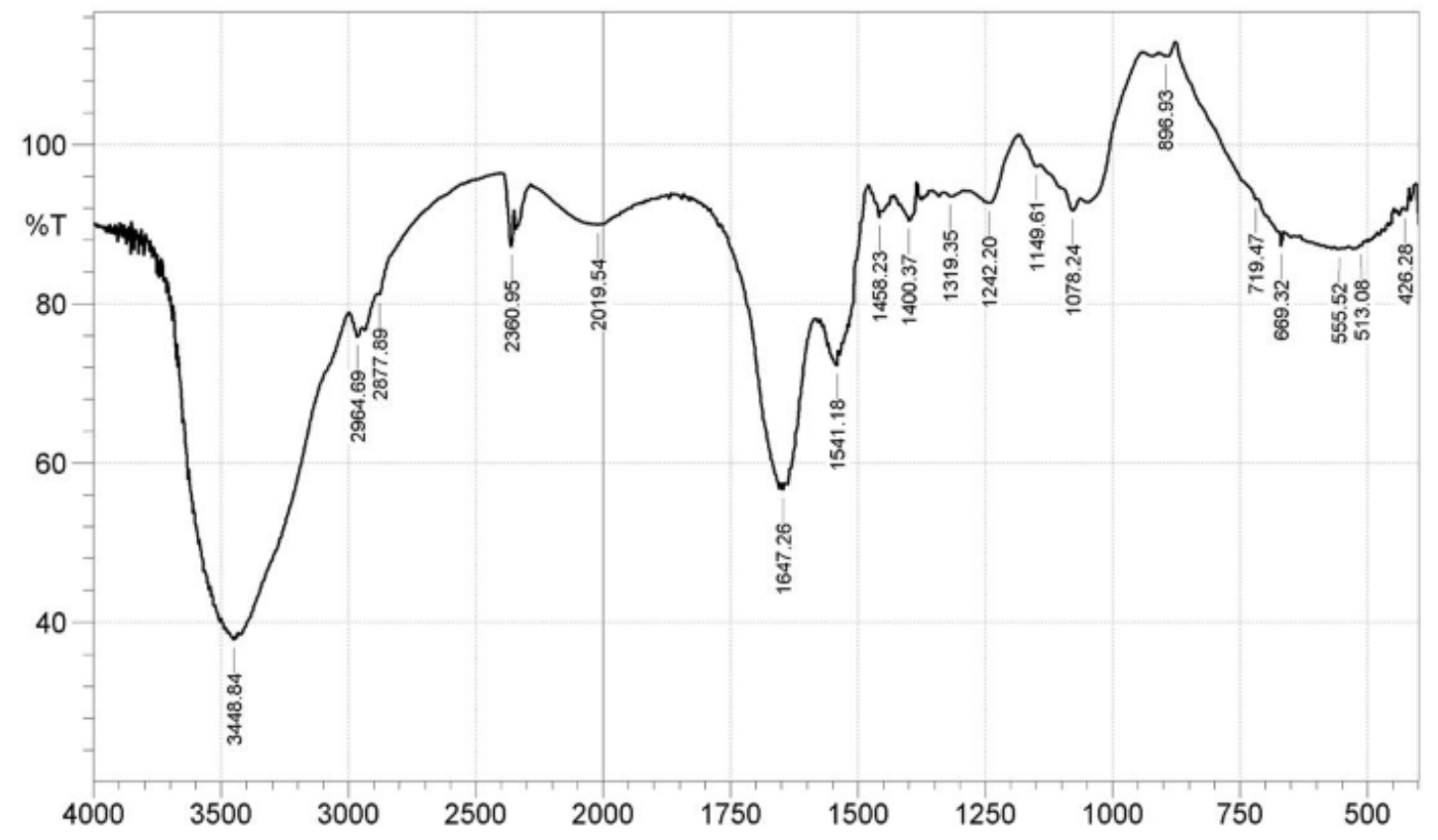

691

692 S10: Laccase CLEA FTIR

693

694

695

696

697

698

699

700

701

702 


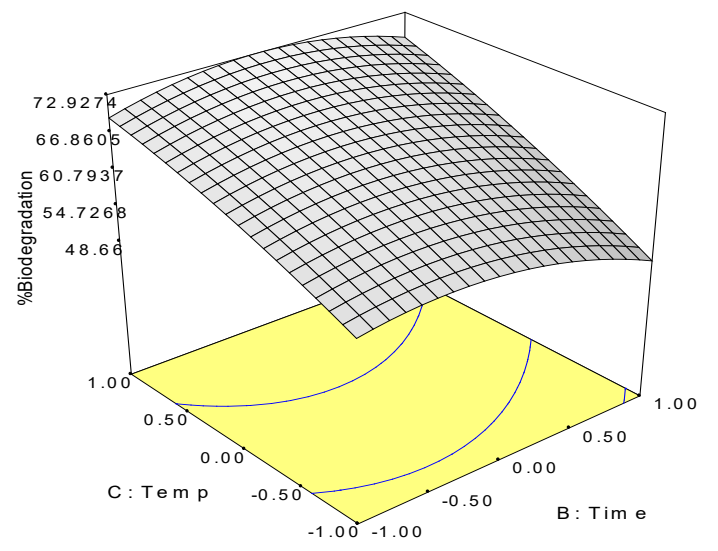

704

706

707
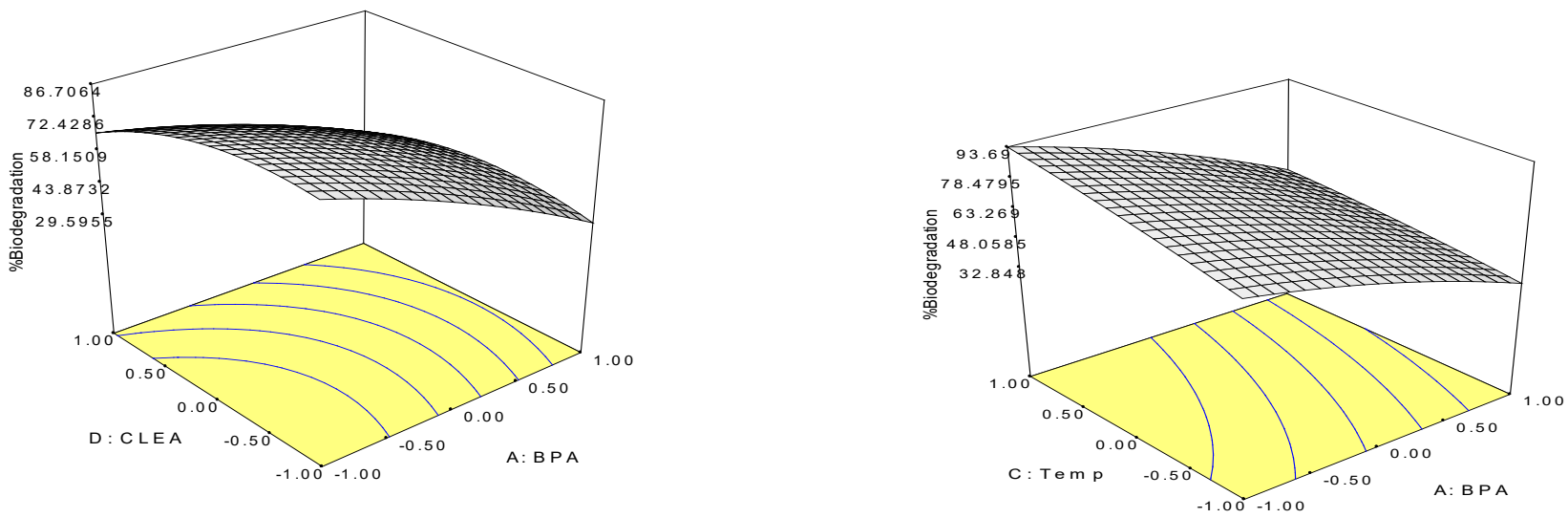

705
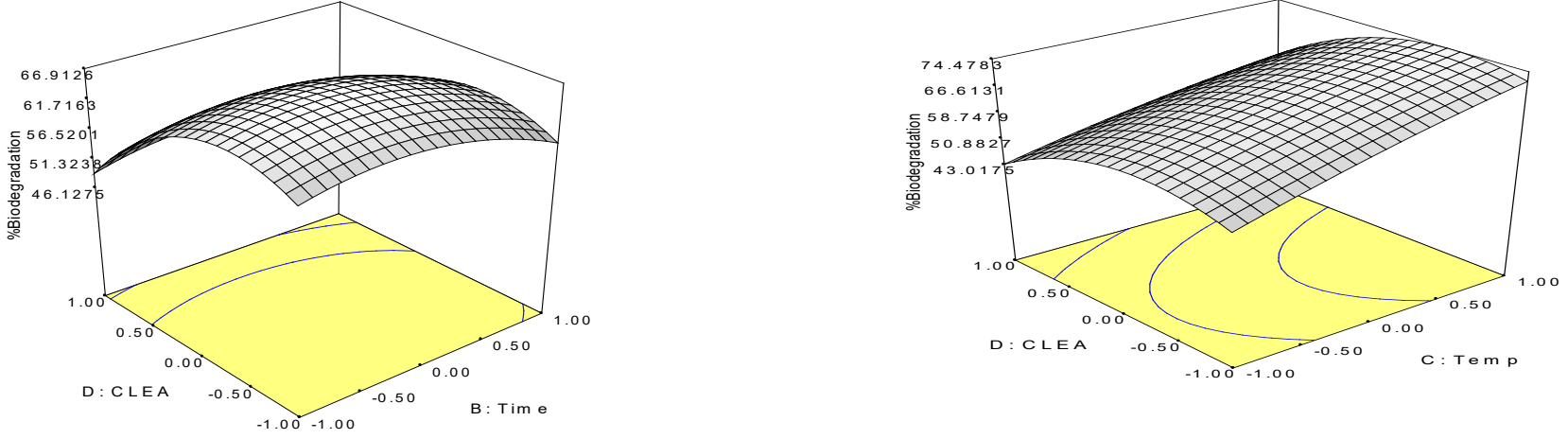

S11: Effect of (A) temperature $x$ time (B) time $x$ [BPA] (C) CLEA amount $x$ [BPA] (D) temperature $x$ [BPA] (E) CLEA amount $x$ time and (F) CLEA amount $x$ temperature on the biodegradation efficiency of CLEA on BPA. 


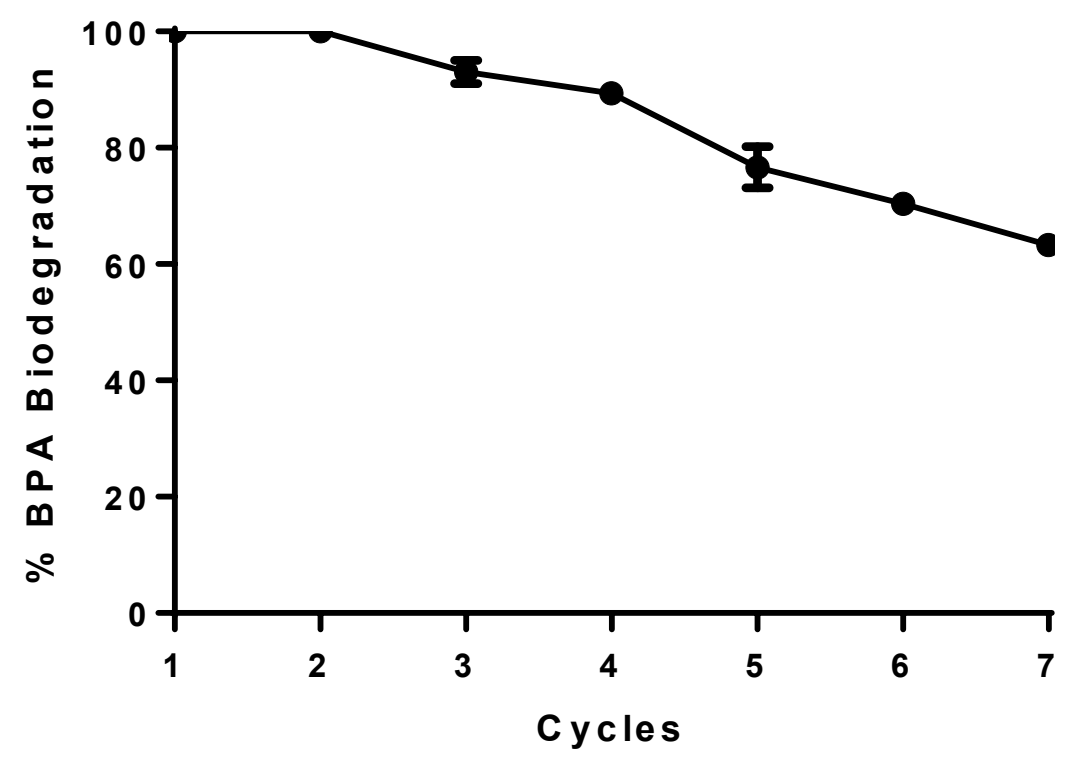

712

713 S12: Reusability of CLEA in BPA biodegradation

714

715 


\section{Figures}

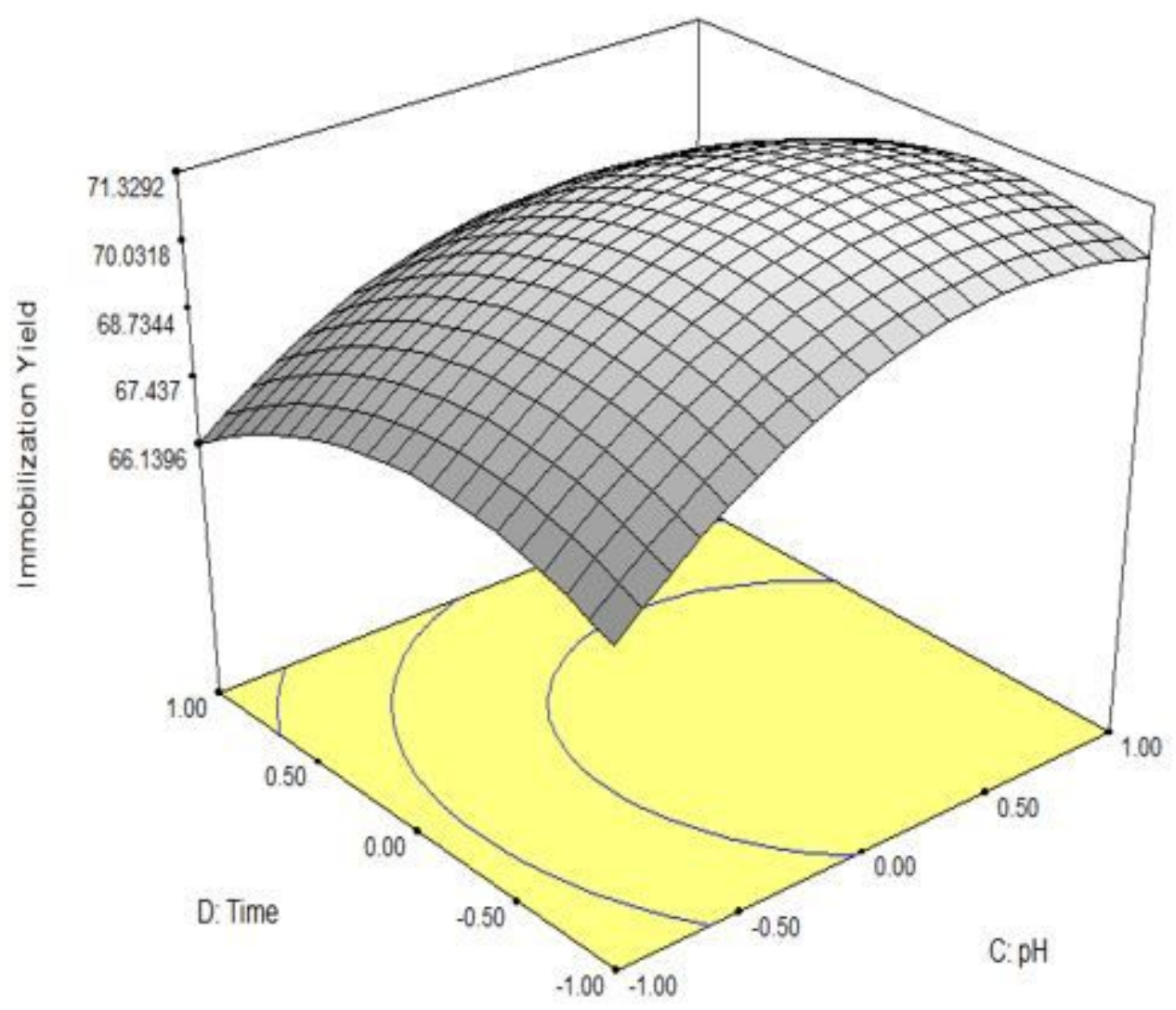

Figure 1

Response surface plots for the preparation of CLEA. Effect of time and $\mathrm{pH}(\mathrm{A})$. The Figures indicating the effects of glutaraldehyde and precipitant (B) precipitant and $\mathrm{pH}(\mathrm{C})$ temperature and time (D) and temperature and $\mathrm{pH}$ on the immobilization yield of the laccase CLEA are shown in the supplementary section. 


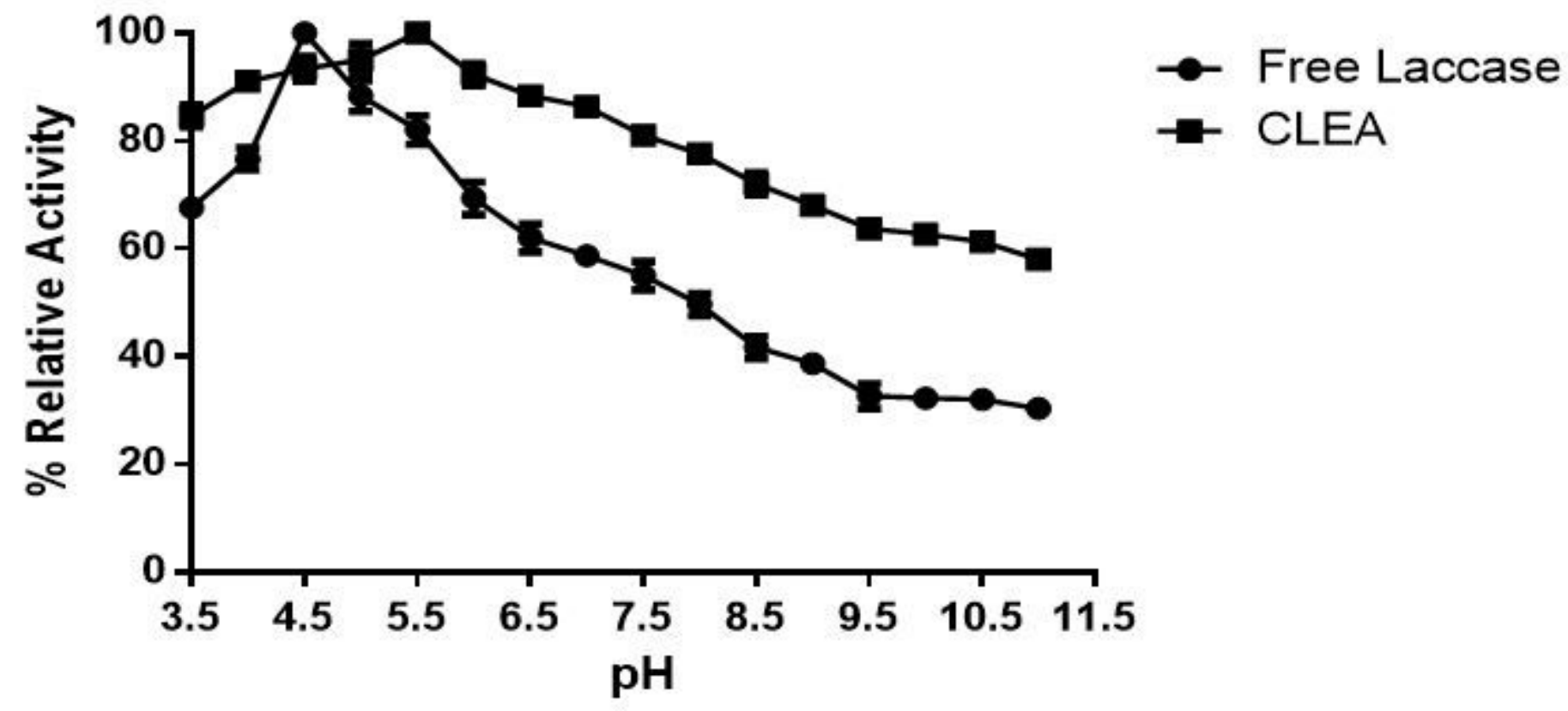

Figure 2

Effect of $\mathrm{pH}$ on free an immobilized laccase 


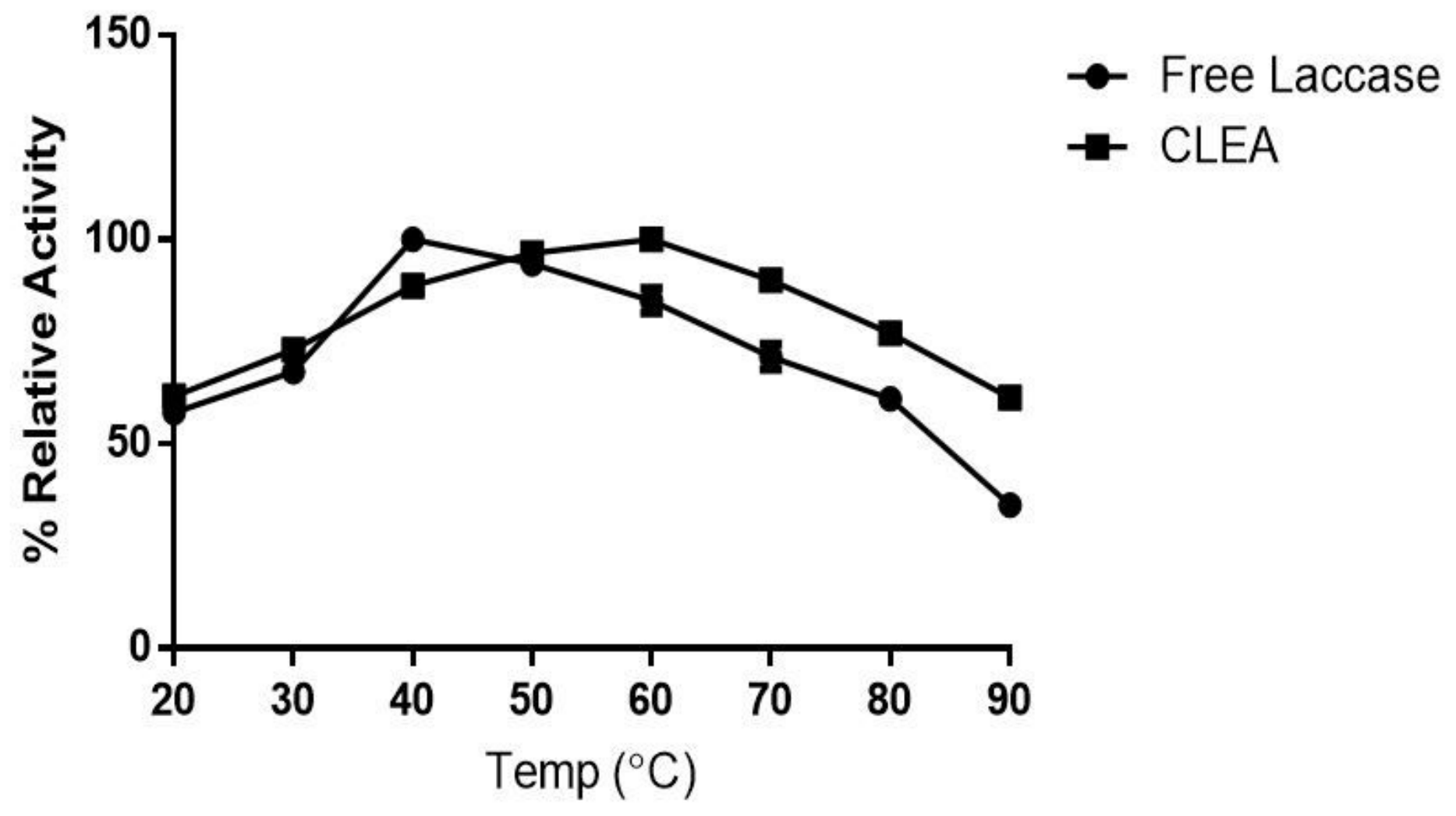

Figure 3

Effect of temperature on free and immobilized laccase

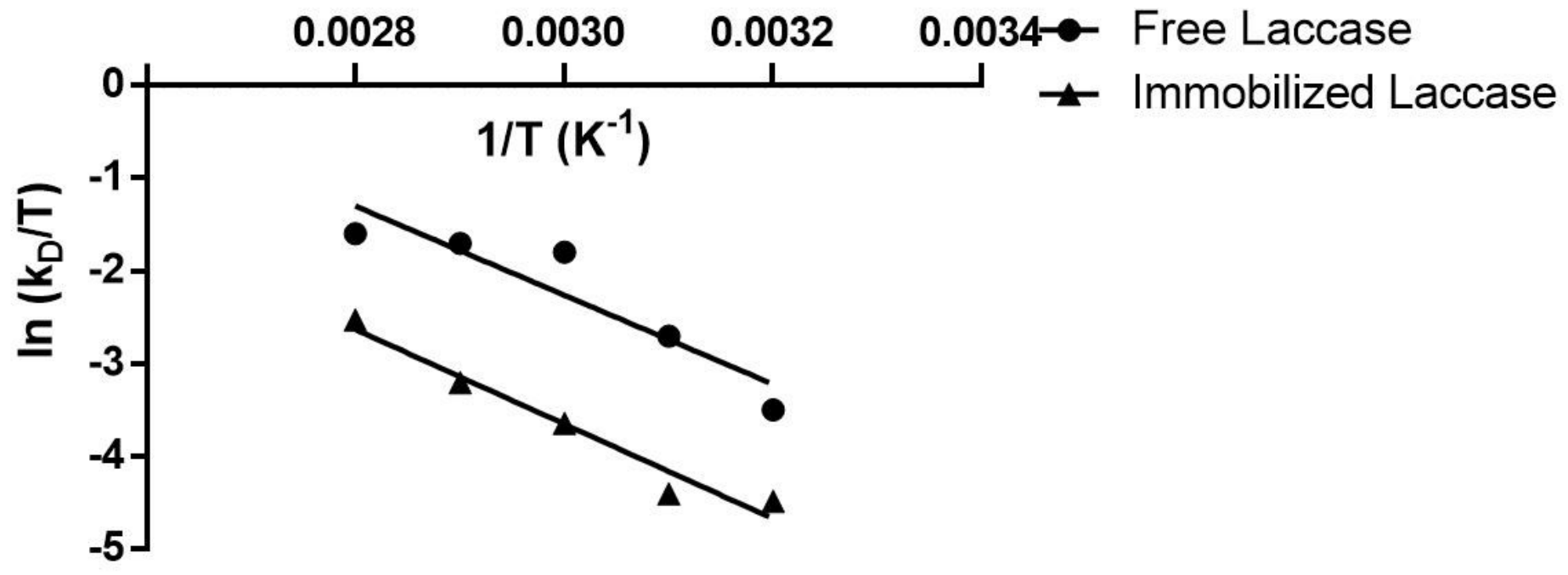

Figure 4

Arrhenius-type plot to estimate the activation energy of thermal denaturation $\left(E_{-} d^{\wedge \star}\right)$ for free and immobilized laccase 


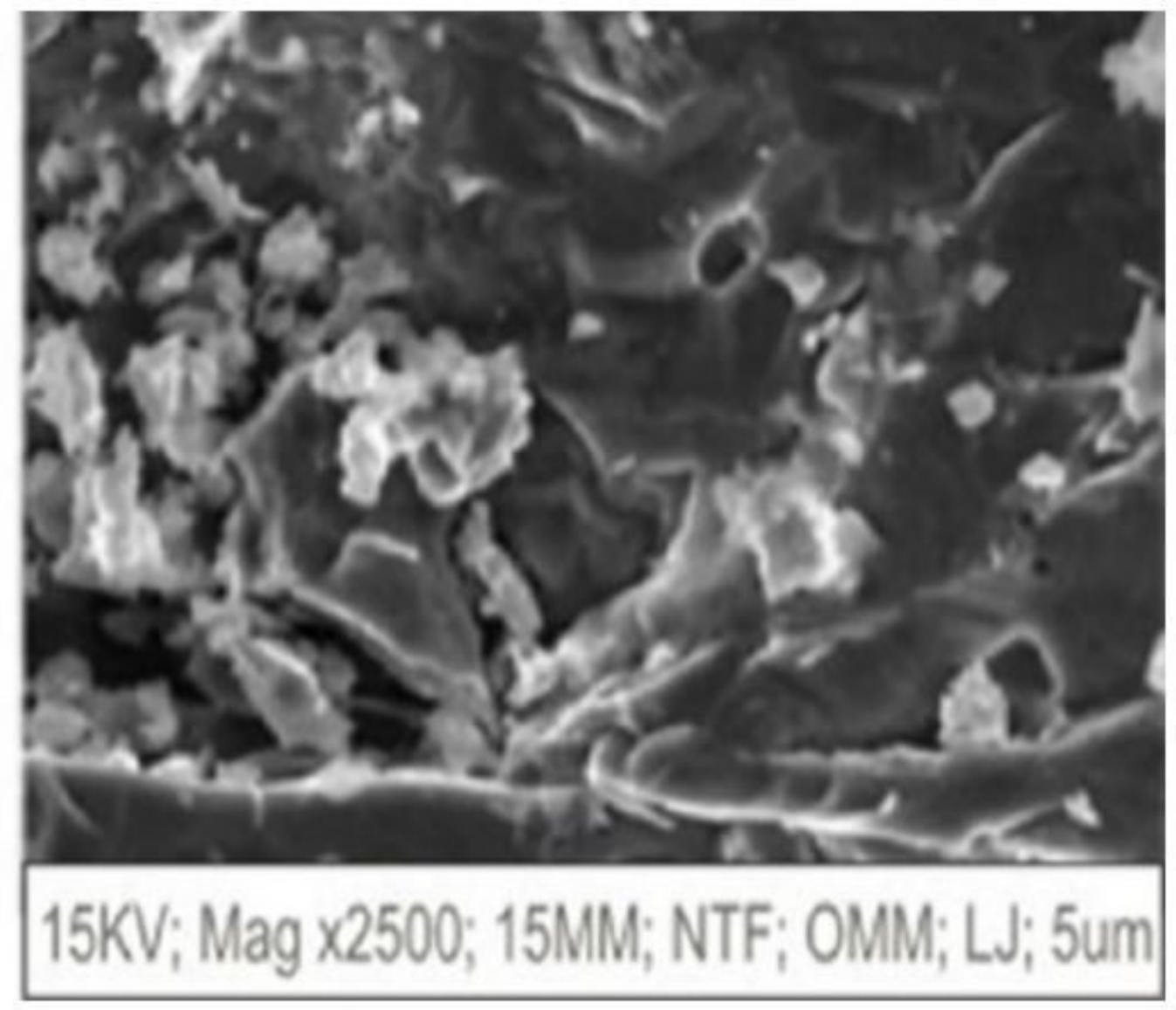

\section{Figure 5}

Scanning electron microscopy of the laccase CLEA

\section{Supplementary Files}

This is a list of supplementary files associated with this preprint. Click to download.

- SiFiles.docx 